\title{
Cell Therapy for Multiple Sclerosis
}

\author{
Tamir Ben-Hur
}

Published online: 9 September 2011

(C) The American Society for Experimental NeuroTherapeutics, Inc. 2011

\begin{abstract}
The spontaneous recovery observed in the early stages of multiple sclerosis (MS) is substituted with a later progressive course and failure of endogenous processes of repair and remyelination. Although this is the basic rationale for cell therapy, it is not clear yet to what degree the MS brain is amenable for repair and whether cell therapy has an advantage in comparison to other strategies to enhance endogenous remyelination. Central to the promise of stem cell therapy is the therapeutic plasticity, by which neural precursors can replace damaged oligodendrocytes and myelin, and also effectively attenuate the autoimmune process in a local, nonsystemic manner to protect brain cells from further injury, as well as facilitate the intrinsic capacity of the brain for recovery. These fundamental immunomodulatory and neurotrophic properties are shared by stem cells of different sources. By using different routes of delivery, cells may target both affected white matter tracts and the perivascular niche where the trafficking of immune cells occur. It is unclear yet whether the therapeutic properties of transplanted cells are maintained with the duration of time. The application of neural stem cell therapy (derived from fetal brain or from human embryonic stem cells) will be realized once their purification, mass generation, and safety are guaranteed. However, previous clinical experience with bone marrow stromal (mesenchymal) stem cells and the relative easy expansion of autologous cells have opened the way to their experi-
\end{abstract}

Electronic supplementary material The online version of this article (doi:10.1007/s13311-011-0073-x) contains supplementary material, which is available to authorized users.

T. Ben-Hur $(\bowtie)$

Department of Neurology, The Agnes Ginges Center for Human

Neurogenetics, Hadassah - Hebrew University Hospital,

Jerusalem 91120, Israel

e-mail: tamir@hadassah.org.il mental application in MS. An initial clinical trial has established the probable safety of their intravenous and intrathecal delivery. Short-term follow-up observed immunomodulatory effects and clinical benefit justifying further clinical trials.

Key Words Multiple sclerosis, stem cell, transplantation, remyelination, immunomodulation.

\section{Introduction}

Although current therapy in multiple sclerosis (MS) is directed at the underlying autoimmune pathogenic process, cell therapy has been advocated as a means of regenerative medicine. In this review, the complexity, advantages, and difficulties in cell therapy will be discussed.

\section{Is Cell Therapy a Valid Option for MS?}

Any discussion of cell therapy for MS needs to first take a look at the endogenous processes of brain repair and their failure to build a rationale for the feasibility and prospects of treatment by cell transplantation.

Glial Progenitor Cells in the Adult Central Nervous System

The identification of neural precursor cells and neurogenesis in the adult central nervous system (CNS) [1-3], including that of humans [4-6], and the identification of persistent neural stem cells (NSCs) as the parental cells from which new neurons are derived [7-14], has revolutionized our concepts of the adult brain as structurally immutable. There are several niches in the adult brain in 
which NSCs persist throughout life and can respond to injurious processes [15-18]. New neurons are continuously generated in the anterior subventricular zone (SVZ) of adult rodents, from which they migrate via the rostral migratory stream to the olfactory bulb [19-23], and in the subgranular zone of the hippocampal dentate gyrus of both adult rodents [24-27] and humans [6, 28]. The subependymal cell layer of the ventricles [29] and spinal cord [30] contains stem cells that give rise to both neurons and glia. Multi-potential precursors are abundant in many regions of the adult brain parenchyma [31-34]. In particular, oligodendrocyte progenitor cells (OPCs) were isolated from various regions of the adult rodent CNS [35-37], and were identified also in the adult human brain [38-42] and spinal cord [43]. OPCs are identified by expression of chondroitin-sulfate proteoglycan NG2+ and of platelet-derived growth factor receptor- $\alpha$ are highly abundant in the adult CNS, comprising up to $5 \%$ of its cells [37].

\section{Adult Precursor Cells can Generate Remyelinating Oligodendrocytes}

The origin of endogenous remyelinating cells in the adult CNS has been subject to multiple studies (for more detail see Franklin and Ffrench-Constant [44]). Differentiated postmitotic oligodendrocytes are unable to rebuild myelin sheaths [45-47] and remyelination is dependent on cycling cells [47, 48]. The notion that OPCs are the main remyelinating cells of the adult CNS emerged from studies showing remyelination after focal demyelination by resident progenitor cells $[49,50]$. Tissue OPCs expressing NG2 and platelet-derived growth factor receptor- $\alpha$ on their cell surface are mobilized in response to demyelination [49, 5153]. Recent studies provided the definitive proof that these cells are indeed the main remyelinating cell in the CNS following a demyelinating injury [54, 55]. In addition, neural precursor cells (NPCs) of the adult SVZ expressing the embryonic polysialylated form of the neural cell adhesion molecule (PSA-NCAM) react to inflammation and demyelination with proliferation, and migration into the tissue and glial differentiation, generating both astrocytes and remyelinating oligodendrocytes [56-59].

\section{Myelin Regeneration Fails in MS}

In MS, the inflammatory process in the CNS leads to demyelination. The affected demyelinated regions can undergo partial remyelination, leading to structural repair and recovery of function [60-63]. Attempts to regenerate myelin can be recognized pathologically in brains of MS patients by the existence of shadow plaques, which are partially remyelinated lesions. Analysis of brain tissue from MS patients suggests there are several different pathological patterns of demyelination [64]. In some patients, there was progressive loss of oligodendrocytes and myelin without reactive remyelination, whereas in others, who exhibited strong T-cell and macrophage activity, there was robust remyelination, indicating the important role of tissue support to the remyelinating response [65]. The sequential involvement of these processes underlies the clinical course, characterized by episodes of relapses, which after full remissions early in the course of disease, eventually leave persistent deficits, and finally deteriorate into a secondary chronic progressive phase. Moreover, remyelination is typically incomplete and ultimately fails in the setting of recurrent episodes contributing to the progressive demyelination, gliosis, axonal damage, and neurodegeneration typically noted in MS [66, 67]. Several studies have indicated that axonal pathology is the best correlate of chronic neurological impairment in MS and its animal model, experimental autoimmune encephalomyelitis (EAE) [68-73].

It is unclear why remyelination fails in time with MS [44, 67]. Some studies showed a depletion of progenitor cells after focal demyelination in experimental animals [52, 74], whereas others showed that repeated episodes of demyelination did not slow down remyelination [75]. In pathological specimens of chronic MS lesions in human patients, neither decrease nor reactive increase was observed relative to normal white matter [39, 76-78]. This suggests that the response of the progenitor cell population to the demyelinating process in the human brain is deficient. In the adult and aging brain, OPC recruitment and differentiation is impaired, resulting in slowed remyelination [79]. This is attributable to age-dependent deficiency in histone deacetylase, allowing the accumulation of transcriptional inhibitors that prevent myelin gene expression [80]. In addition cell migration seems to be another limiting factor in myelin regeneration. Progenitor cells that reside at the margins of experimental lesions migrate into the lesion core and remyelinate it, but long distance migration does not occur in the brain parenchyma [50,81]. The limited recruitment of adult CNS OPCs into demyelinated lesions may be also related to their apparent dormant state. Adult OPCs are very slow cyclers [82], and they require prolonged exposure to multiple growth factors before they convert into rapidly proliferating cells [34, 83]. Thus, precursors derived from the developing CNS may have superior migratory and remyelinating capabilities than endogenous precursors.

The questions of whether remyelination failure originates from malfunction of resident OPCs or is due to the lack of permissiveness of the adult CNS, and whether the causes to failure are reversible, represent crucial issues in the discussion on the prospects of replacement cell therapy in MS. For example, there is evidence that extensive axonal transections already occurs in acute MS lesions [84]. Remyelination cannot effectively proceed in the absence 
of sufficient intact axonal substrate, so that it may be effectively rate-limited by the extent of underlying axonal loss. Therefore, achieving remyelination prior to development of axonal damage is crucial to any therapeutic strategy. Alternatively, if reversible cell autonomous factors or inhibitory factors that are expressed in the demyelinated tissue limit OPC differentiation into remyelinating oligodendrocytes, then the rationale treatment would be to target them directly. Active inhibition of resident OPCs is suggested by the sharp border of demyelinated plaque, surrounded by OPCs [39, 76, 77]. It was suggested, for example, that re-expression of Notch1, a regulator of oligodendrocyte progenitor differentiation, inhibits remyelination in MS [85]. Yet targeted ablation of Notch1 did not enhance remyelination in experimental animals [86]. It was further recently shown that failure of OPC differentiation was due to cytoplasmic entrapment of the intracellular domain of Notch1 as a result of abnormal expression of TAT-interacting protein $30 \mathrm{kDa}$ (TIP30), an inhibitor of importin-mediated nuclear transport [87]. Several strategies have been proposed to overcome the intrinsic block or extrinsic inhibition of OPC response to facilitate the endogenous process of myelin repair. One approach is to increase the recruitment and number of cycling OPCs by growth factor treatment. Candidates include platelet-derived growth factor [88-90], neuregulin-1, which is not essential for myelination in the CNS but can induce hypermyelination when overexpressed [91], and epidermal growth factor [59]. In addition, sonic hedgehog signaling stimulates the maintenance and renewal of neural precursors in the neurogenic niches of the adult brain [92, 93]. Recruitment and mobilization of OPCs and multipotential neural precursors in the models of MS have been mainly attributed to the inflammatory process. Brain inflammation attracts the migration of both endogenous [57] and transplanted [94-97] precursor cells. Various inflammatory cytokines can induce neural/oligodendrocyte precursor cell migration. Transforming growth factor- $\beta$ induces microglia to release hepatocyte growth factor, which increases OPC migration [98]. Tumor necrosis factor- $\alpha$ increases the motility of neural precursors in vitro [99]. The chemokine stromal derived factor 1 (CXCL12) induces neural stem/precursor cell migration in models of stroke [100,101], viral-induced demyelination [102], and trauma [103]. In addition, the injection of inflammatory stimuli in an ex vivo model of hippocampal slices attracted neural precursors, depending of monocyte chemoattractant protein (MCP-1) signaling via the CCR2 receptor [104]. Moreover, inflammation stimulates the remyelinating process $[105,106]$. The apparent link between the acute inflammatory phase and setting of regenerative processes in motion may define a narrow time window when remyelination is feasible. The necessity to remyelinate before axonal damage occurs, and the limited time window of opportunity in face of the dormant state of resident progenitors, may cause a temporal mismatch underlying remyelination failure [105]. However, although this time window may be too narrow for adequate endogenous progenitor cell mobilization, it may suffice for therapeutic cell transplantation. Another approach to push remyelination is to force OPC differentiation. Among several neurotrophic factors tested, the ciliary neurotrophic factor family was found to promote oligodendrocyte differentiation and remyelination [107]. More recently, pharmacologic induction of OPC differentiation by inhibition of RhoA-Rho-kinase II (ROCK-II), and/or protein kinase C signaling [108], or by anti-Leucine-rich repeats and Ig domain-containing, neurite outgrowth inhibitor (Nogo) receptor-interacting protein-1 (LINGO1) antibodies [109, 110] accelerated remyelination. Statins and inhibitors of receptor tyrosine phosphatases are other pharmacologic agents that induce rodent [111] and human [112] oligodendrocyte differentiation. However, when tested in the cuprizone model of demyelination in vivo, statin therapy inhibited remyelination [113]. Olig1 is an important transcription factor in early oligodendrocyte specification and differentiation. Its induction may stimulate remyelination [114]. Analysis of gene expression profiles during development in the normal adult brain and during demyelination identified several novel regulatory pathways of oligodendrocyte differentiation. These studies showed that oligodendrocyte differentiation and remyelination are dependent on retinoid-X receptor-gamma receptor agonists [115] and on Wnt-beta-catenin signaling [116]. In addition, type 2 cyclin dependent kinase (also known as cdk2), which controls the cell cycle, does not interfere with myelination during development, but its knock-out facilitates remyelination [117]. These exciting findings open novel therapeutic targets for enhancing remyelination. In addition, they highlight the discussion on whether the preferable regenerative therapeutic strategy in MS will be by cell transplantation or by boosting up endogenous remyelination, or both.

\section{The Therapeutic Plasticity of Stem Cells}

\section{Cell Replacement}

Transplantation of both rodent and human OPCs and various types of neural precursor cells has shown their potential in remyelinating the CNS. This has been established both in models of genetic dysmyelinating disorders (for more details see Goldman et al. [118]) and models of acquired demyelination in the adult rodent CNS (for more details see Ben-Hur and Goldman [119], Yang et al. [120], Miron et al. [121], and Martino [122].

Early studies focused on oligodendrocyte progenitors with the notion of cell replacement (i.e., remyelination) 
therapy in mind. Although postmitotic oligodendrocytes have poor remyelinating capacity [123], their immediate progenitors exhibit greater mitotic, migratory, and regenerative properties in both genetic dysmyelinating and adult focal demyelinating models of disease [124-127]. Transplanted rodent OPCs myelinated nude axons and restored nerve conduction velocity to near normal values in the spinal cord of $m d$ rats [128], and canine OPCs repaired large brain areas in the sh pup [126].

Human OPCs showed similar properties as their rodent counterparts, and myelinated efficiently in models of focal demyelination $[127,129]$ and of congenital dysmyelination [42]. The in vitro propagation of glial precursors necessitates continuous mitogenic exposure to obtain a sufficient amount of cells. An alternative approach that may circumvent the potential negative effects of prolonged in vitro cell expansion may be by high scale selective isolation of precursor cells. For example, precursor cells could be isolated from dissociated fetal and adult CNS tissue by transfection with a plasmid encoding green fluorescent protein (GFP) placed under the control of the 2',3'-cyclic nucleotide 3'phosphodiesterase-2 (CNP2) promoter, a regulatory element activated in early oligodendrocyte progenitor cells, followed by fluorescence activated cell sorting [40, 42, 127]. Alternatively, fluorescence-activated or immunomagnetic sorting were used to isolate A2B5(+)/poly-sialic acid-neural cell adhesion molecule (PSA-NCAM)(-) fetal and adult human glial progenitors [42]. Highly efficient and widespread donor-derived myelination was obtained with these human precursors within a month of transplant to newborn shiverer mice [42], which are congenitally deficient in myelin basic protein [130]. Additional intracerebellar injection resulted in substantial infiltration and myelination of cerebellar white matter, peduncles, and dorsal brainstem [131]. Importantly, the transplanted shiverers lived significantly longer than their un-transplanted controls, and a fraction of the mice appeared to be completely rescued in terms of survival and neurological disability [131]. In correlation, donor-derived myelin sheaths had the ultra-structural architecture of compact and functional myelin [131]. Interestingly, fetal and adult-derived human glial precursors demonstrated different functional properties; fetal progenitors emigrated more widely and engrafted more efficiently than adult cells, but the adult progenitors generated oligodendrocytes more efficiently, and myelinated recipient brains much more rapidly and with more axons per donor cell than did fetal cells [42].

Several studies examined whether earlier stages of neural precursor cell development also may be valuable for remyelinating therapy. The potential advantages in NSCs are as nontransformed cells that are able to self-renew indefinitely, allowing their expansion in large quantities. As discussed, mammalian multi-potential NSCs support neurogenesis and gliogenesis within specific areas of the CNS during development and adulthood, and can be isolated from fetal and adult brains $[10,132,133]$. The notion that glial committed neural stem cells may combine the capacity for self-renewal and plasticity of stem cells, together with the remyelinating properties of OPCs, led to identification of such precursors in the developing brain [134]. Expression of PSA-NCAM on the cell membrane has been associated with stem cell commitment to neuronal or glial fate, depending on time and place in development [135137]. Indeed, such PSA-NCAM+ glial precursors, growing as neurospheres and also termed as oligospheres $[135,138]$, efficiently myelinated the brains of shi mice [138-140], remyelinated 95 to $100 \%$ of axons following local injection into the dorsal columns of rats [141], and efficiently migrated along inflamed white matter tracts of rats with EAE [94, 95]. Similarly, adult human SVZ precursors remyelinated the adult rat spinal cord [142]. Finally, multipotential NSC also showed a capacity to perform efficient myelination in the spinal cords of shiverer mouse, $m d$ rat, and sh pup [143-145], as well as in adult animals with traumatic spinal cord injury [146, 147]. However, before discussing which cell type is the optimal remyelinating cell for clinical translation in MS, it is important to point out that many of these studies have not yet established the necessary proof-of-concept for cell therapy-based myelin repair in MS. When focal demyelinated lesions were induced by myelinotoxic chemicals, such as ethidium-bromide, lysolecithin, or cuprizone [148-150], it was followed by a rapid process of remyelination by endogenous cells. In fact, a prerequisite in all of these models to be able to show transplant-derived remyelination was the prior removal of endogenous OPCs, by means such as X-irradiation. Moreover, transplantation experiments have been typically performed during the acute phase, immediately after lesion induction. Obviously, these experimental models do not represent the complexity of the chronic MS brain, in which resident OPCs are present, but fail to perform their duties. EAE is considered the closest animal model to human MS, and served for the development of several immunotherapies. However, EAE has not proven useful for developing the cell transplantation approach for remyelination. A central problem is that the existing chronic EAE models have an extensive axonal pathology at the early acute phase, which does not allow any myelin repair [151]. Thus, there is urgent need for a clinical relevant model of remyelination failure where the potential of cell therapy may be examined properly. In particular, such models would serve to both develop and test therapeutic approaches to accelerate remyelination in the adult CNS and to examine whether the supply of exogenous myelin-forming cells has any advantage in comparison to endogenous precursors.

Although cell therapy was originally believed to be primarily a means of replacing damaged cells in the CNS, 
transplantation experiments in several pre-clinical models of neurological disorders showed that the remarkable functional recovery obtained at NPC transplantation does not correlate with the amount of terminally differentiated neural cells originating from transplanted NPCs (for more details see Martino and Pluchino [152]). Multiple studies have pointed at other powerful mechanisms of actions by which transplanted cells exhibit a beneficial effect, termed collectively as therapeutic plasticity of stem cells.

\section{Trophic Support by Transplanted Precursor Cells}

Recent studies have focused on several bystander neuroprotective and neurotrophic properties of transplanted NPCs. The NPCs seeded on a synthetic biodegradable scaffold and grafted into the cord of hemi-sectioned rats induced significant clinical recovery, which was associated with reduced necrosis and limited secondary cell loss, inflammation, and glial scar formation of the surrounding parenchyma [153]. Moreover, the NPC graft induced a permissive environment for axonal regeneration [153]. Injection of biodegradable scaffolds loaded with NPCs into hypoxic brain regions induced substantial endogenous reconstitution of the brain structural connectivity [154]. A similar effect was observed following intracerebral transplantation of NPCs after ischemia/reperfusion injury in mice [155]. In a Parkinson's disease model, transplanted NPCs rescued endogenous dopaminergic neurons of the mesostriatal system [156], and in models of amyotrophic lateral sclerosis transplanted NPCs prevented motor neurons from dying [157-159]. Transplantation experiments in models of spinal cord injury have provided several insights to the basic biological mechanisms by which the various types of precursor cells exhibit their therapeutic functions (for more detail see Einstein and Ben-Hur [160]). First, neural and mesenchymal stem and progenitor cells reduce the acute deleterious inflammatory process and induce a permissive environment for axonal regeneration after spinal cord injury [161]. They produce a myriad of neurotrophic growth factors [162], and induce matrix metalloproteinases that degrade the extracellular matrix and cell surface molecules that impede axonal regeneration, thus enabling axons to extend through the glial scar [163]. In addition, the increased bioavailability of neurotrophins, such as nerve growth factor, brain-derived neurotrophic factor, ciliary neurotrophic factor, and glial-derived neurotrophic factor [162], attributes to the NPCs-driven bystander effect in increasing the survival and/or functions of endogenous glial and neuronal progenitors surviving to the pathological insult. Also, cell transplantation into the injured spinal cord provides proper realignment and guidance to enable axonal regeneration along long fiber tracts [164], and induces angiogenesis in the lesioned tissue, which provides trophic support and enables tissue repair [165]. Finally, transplanted cells increase remyelination in the lesion by both endogenous and graft-derived myelin forming cells to enhance action potential conduction and limit secondary axonal degeneration [166].

Recent work has also indicated that transplanted stem cells, including NPCs, can enhance endogenous neurogenesis in certain physiological and pathological conditions [167, 168]. Mice exposed prenatally to opioids display impaired learning associated with reduced neurogenesis, and transplantation of NPCs improves learning functions, as well as host brainderived neurogenesis in the dentate gyrus of the hippocampus [169]. A similar neurotrophic effect was also reported in physiological aging. Although neurogenesis in the dentate gyrus declines severely by middle age, transplantation of NPCs stimulates the endogenous NPCs in the subgranular zone to produce new dentate granule cells [167]. With more direct relevance to remyelination failure, a recent study of a chronic cuprizone-induced demyelination model in aging mice showed that transplanted NPCs facilitated the endogenous process of remyelination [170]. This effect was mediated by induction of resident OPCs proliferation and their differentiation [170].

Thus, transplanted NPCs may enhance the adult CNS capacity to repair itself by restoring the ability of endogenous progenitors to respond properly to the diseased state and replace damaged CNS cells. In particular, stem/ precursor cell therapy may serve as an approach to overcome the failure of endogenous remyelination in MS.

\section{Immune Modulation}

The first indication of a novel anti-inflammatory effect of NPCs was obtained when neurospheres were transplanted intracerebroventricularly (ICV) in acute spinal cord homogenate-induced EAE Lewis rats [171]. This model manifests with acute reversible paralytic disease that is the result of disseminated CNS inflammation without demyelination or axonal injury [172]. NPC transplantation in spinal cord homogenate-induced EAE Lewis rats attenuated the inflammatory brain process and clinical severity of disease [171]. Follow-up studies examined the effect of NPC transplantation on either ICV or intravenous cell injection in the myelin oligodendrocyte glycoprotein (MOG) 35-55 peptide-induced EAE in C57BL/6 mice. In this model, a T cell-mediated autoimmune process causes an acute paralytic disease due to severe axonal injury and demyelination. Subsequently, the mice remain in a fixed neurological sequel, the severity of which is correlated with the extent of axonal loss [73]. NPC transplantation in MOG35-55-induced EAE mice attenuated brain inflammation, reduced acute and chronic axonal injury and demyelination, and improved the overall clinical and neurophysiological performance of the 
CNS of the mice $[173,174]$. Finally, such immune regulatory properties were also shown for human embryonic-stem cellderived NPCs in rodents [151] and for somatic NPCs in primates [175]. Again, the therapeutic effects of both these latter NPC sources was not related to graft- or host-driven remyelination, but rather were mediated by an immune regulatory mechanism that protected the CNS from immunemediated injury [151].

In the CNS, NPC-mediated bystander immune regulation may take place in the ventricular space and white matter tracts [176], as well as at the level of the atypical perivascular niches [97, 152, 173]. Following systemic delivery, immune regulation by NPCs occurs in secondary lymphoid organs, such as the lymph nodes [177] or the spleen [178].

Several mechanisms were suggested to explain how transplanted NPCs attenuate CNS inflammation. One school of thought was suggested that NPCs induce apoptosis of Th1 cells, but not Th2 cells, selectively, via the inflammationdriven up-regulation of membrane expression of functional death receptor ligands (e.g., Fas Ligand, TNF-related apoptosis-inducing ligand-TRAIL, Apo3 ligand) on NPCs [173]. Alternatively, it has been suggested that NPCs inhibit T-cell activation and proliferation by a nonspecific, bystander immune suppressive action [177]. This notion emerged from co-culture experiments that showed a striking inhibition of the activation and proliferation of EAE-derived, as well as naive, T cells by NPCs, following stimulation by various stimuli $[171,177,179]$. The suppressive effect of NPCs on T cells was accompanied by a significant suppression of proinflammatory cytokines, such as interleukin (IL)-2, tumor necrosis factor- $\alpha$, and interferon- $\gamma$ [177]. Moreover, NPCs inhibited multiple inflammatory signals, as exemplified by attenuation of the T-cell receptor IL-2- and IL-6-mediated immune cell activation and/or proliferation [179]. The relevance of such NPC/T-cell interaction was first suggested when NPCs were intravenously injected prior to EAE disease onset (e.g., at 8 days after the immunization) and were transiently found in peripheral lymphoid organs, where they interacted with $\mathrm{T}$ cells to reduce their encephalitogenicity [177]. In a similar fashion, when NPCs were subcutaneously injected they targeted secondary lymphoid organs, where they interacted with immune cells and stably modified (e.g., for more than 2 months after cell injection) the perivascular microenvironment. Within this context, surviving NPCs stalled the activation of myeloid dendritic cells via a bone morphogenetic protein-4-dependent mechanism, which was completely reverted by the bone morphogenetic protein antagonist Noggin [180].

\section{Therapeutic Plasticity of Non-Neural Stem Cells}

Neurotrophic and immune regulatory properties seem to be a common property of stem cells from various sources. This was most thoroughly studied in bone marrow stromal (mesenchymal) stem cells (BMSC). These cells form the bone marrow stroma that support hematopoiesis [181] and serve as precursors of the various bone cell types (adipocytes, myocytes, and chondrocytes) [182]. They do not express hematopoietic markers and can be identified by expression of CD105, CD44, CD 90, and others. The neurotrophic properties of these cells were demonstrated in several models of neurological diseases, including stroke [183] and trauma [184]. BMSC possess wide immunomodulatory functions; they inhibit maturation of monocytes into dendritic cells [185], they impair the antigen-presenting function of dendritic cells [186, 187], they inhibit T-cell proliferation in a non-major histocompatibility complex (MHC) restricted manner [188-190], they induce a shift of T cells to an antiinflammatory (IL-4 producing) phenotype [190], and they inhibit B-cell proliferation and differentiation [191]. Several soluble factors have been implicated in the immunomodulatory functions of BMSC, such as indoleamine 2,3dioxygenase, transforming growth factor- $\beta 1$, hepatocyte growth factor, IL-10, and others, but these effects were also partially dependent on cell-cell contact (for more details see Uccelli et al. [192]). Clearly, there is no single factor that is responsible for the diverse BMSC effects. BMSC exhibited powerful immunomodulatory effects in various conditions in vivo. Specifically, intravenously injected BMSC effectively attenuated EAE [193, 194], resulting in efficient protection of the CNS from tissue injury [195].

In conclusion, the observation that stem cell (from various sources) transplantation attenuates the clinical course of EAE ignited clinical translation and application of cell therapies in MS. Different types of stem cells share common immunomodulatory and neurotrophic properties, which can be exploited both systemically and in the CNS. When delivered directly into the CNS, then cell therapy may provide trophic support and induce repair, as well as a broad acting, yet tissue specific immunomodulatory effect, as compared to all other systemic immune therapies (Fig. 1).

\section{Practical Aspects of Cell Therapy Are Issues for Basic Research}

In genetic dysmyelinating diseases transplanted cells integrate into the normal developmental program of the CNS. This leaves us essentially with choosing the optimal myelin-forming cell for transplantation and producing the large mass of cell necessary for widespread CNS myelination. The chronic and multi-focal nature of MS along with hindrances to repair in the adult brain raise several additional crucial issues of timing, route of cell delivery, and long-term survival of grafted cells in such a "hostile environment." The basic biological mechanisms governing 
Candidate cell population

Mechanisms of action

\section{Proven effects vs. unsolved issues}

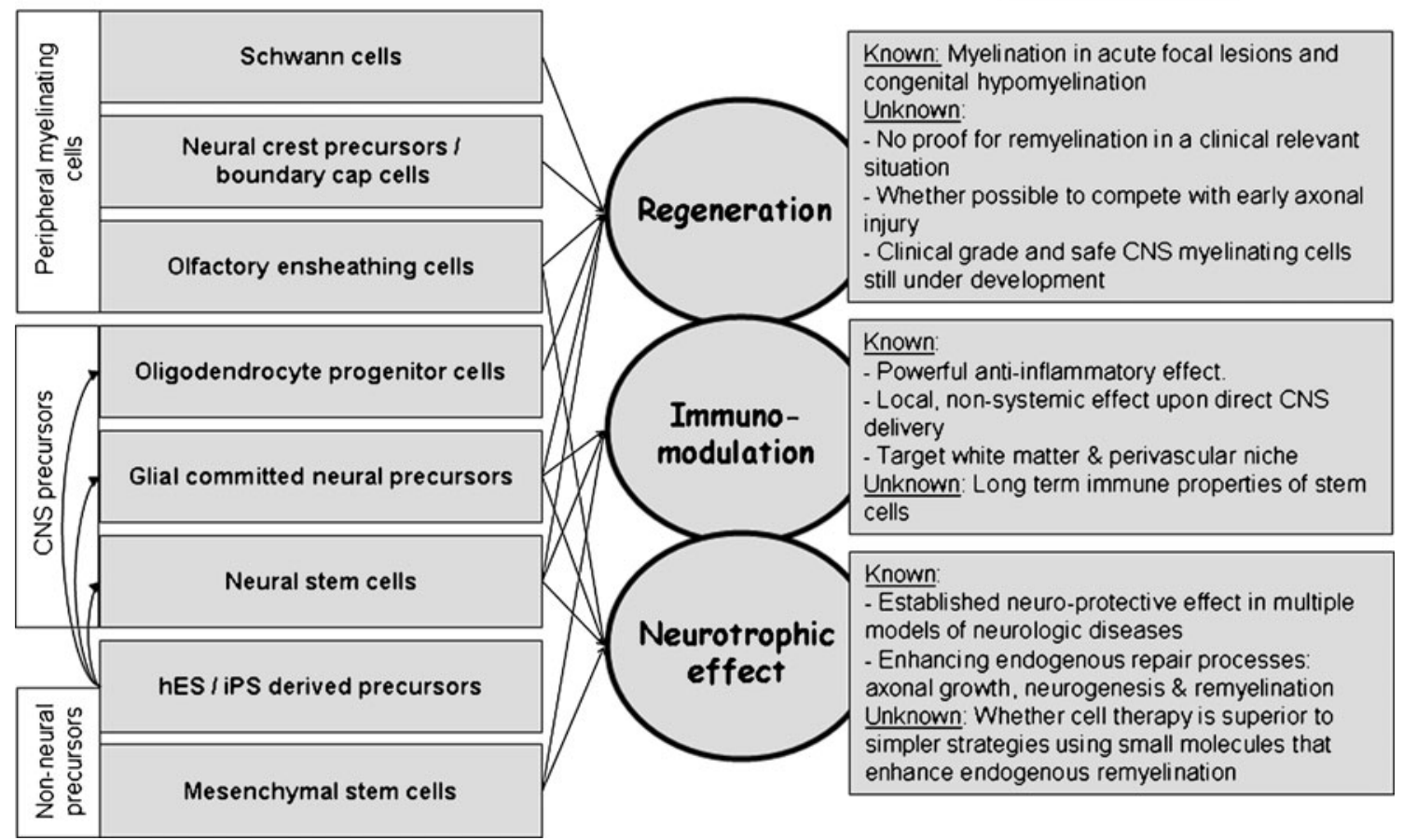

Fig. 1 Using the therapeutic plasticity of stem cells and myelinforming cells in multiple sclerosis, each candidate cell type should be evaluated in terms of its regenerative capabilities, immunomodulatory properties, and trophic effects. The arrows show proven mechanisms of action by the various cell types. Although the therapeutic effects

these aspects need to be studied to bring the therapeutic cell transplantation approach closer to clinical reality.

\section{What Type of Cell to Transplant?}

Various cell types have been considered as candidates for therapeutic transplantation in MS. These include immediate glial progenitors of the oligodendrocyte lineage, earlier neural precursor and stem cells, non-CNS myelin forming cells, and non-neural cell populations. There is still no consensus regarding the optimal donor cell phenotype, but some generalities can be made to compare the relative merits of various candidate cell populations.

\section{Neural Stem and (Oligodendro-) Glial Precursor Cells}

In view of the multiple mechanisms by which neural precursor cells may induce beneficial effects in MS, including their regenerative potential, their trophic, immunomodulatory, and neuroprotective properties, they seem to be an excellent candidate for cell therapy. Specifically, they may have an advantage on committed myelin forming cells that might not possess other stem cell properties, and on non-neural cells that cannot perform remyelination. How- achieved by each of these mechanisms have been studied, there are still many "unknowns." These unknowns represent important areas of future research. $\mathrm{CNS}=$ central nervous system; hES=human embryonic stem; iPS = induced pluripotent stem cells

ever, these hypotheses need to be examined in clinically relevant models, as previously discussed. In addition, the value of transplanting purified cell populations versus a mixture of stem cells and OPCs that need to be directly compared.

\section{Embryonic Stem and Induced Pluripotential Cells}

The practical limitations in getting sufficient human oligodendrocytes prompted research on deriving tissuespecific progenitor cells from human embryonic stem cells. Embryonic stem (ES) cells are derived from the inner cell mass of blastocyst-stage embryos, and are pluripotent cells that are able to generate the entire repertoire of cell types in the body. Glial precursors with myelinogenic properties were derived from mouse ES cells [196-198]. Human ES cells [199, 200] can be directed into neural fate [201, 202]. Recent studies have discovered the means to mimic the tightly controlled human embryonic developmental program to produce highly enriched populations of specific neurons [203-206] and oligodendrocytes [207, 208]. Human embryonic stem cell-derived oligodendrocytes appear functional and capable of myelination [207, 209]. Clinical translation will need to deal with the much feared 
potential for tumorigenesis [210]. In particular, human embryonic stem cell-based therapies might give rise to teratomas, growing from persistent undifferentiated ES cells in the graft [211], or neuroepithelial tumors arising from incompletely differentiated neural cells [212]. Purification of clinical grade and "safe" human ESC-derived glial precursors may be achieved by the same technologies that were developed for isolating these cells from the human brain $[42,131]$

Although the use of ES cells dictates an allogeneic donor cell source, the recent generation of induced pluripotential stem (iPS) cells from somatic mouse [213] cells and from human $[214,215]$ cells may alleviate this limitation. iPS cells are similar to ES cells in their pluripotency, as defined by their ability to generate cells of all major germ layers and teratomas in vivo. Importantly, initial reports have validated their ability to generate functional postmitotic neurons [216-218] and oligodendrocytes [219, 220]. It will now be necessary to explore the potential for generating populations of iPS-derived oligodendrocytes for autologous grafting in the myelin disorders.

\section{Non-CNS Myelin Forming Cells}

\section{Schwann Cells}

These peripheral myelin-forming cells can myelinate CNS axons very efficiently [221-223]. Their transplantation into the CNS resulted in production of compact myelin [223, 224] and restoration of normal conduction velocity in the dorsal columns of the spinal cord, predicting functional recovery [221, 225-228]. They can be isolated from a sural nerve biopsy, expanded in culture, and eventually delivered as an autologous graft to a demyelinated focus in the CNS. As autologous cells, they might obviate the need for immunosuppressives, while concurrently escaping the autoimmune attack of MS, which is typically directed against the central myelin antigens. A clinical trial of Schwann cell transplantation was performed into single demyelinating lesions in 3 MS patients in 2001 at Yale University. The surgical procedure proved to be safe, but the study was discontinued in early 2003, after follow-up brain biopsies could not demonstrate either Schwann cell survival or new myelin formation. It is not known whether this failure resulted from poor cell preparation, autoimmune attack, or if it was due to a lack of integration of peripheral myelinating cells in the adult human brain environment. Although this study has dampened further clinical experimentation with Schwann cell transplants, recent reports renewed interest in using Schwann cell precursors isolated from the neural crest. These cells, and specifically boundary cap cells, which form the border between the developing peripheral and CNS, generate myelinating Schwann cells
[229]. Their increased migratory and myelinating properties [230], as well as their potential to also generate myelinating oligodendrocyte [231], make Schwann cells another promising candidate for cell replacement therapy in myelin disorders.

\section{Olfactory Nerve Ensheathing Cells}

Olfactory nerve ensheathing cells (OECs) display properties of both astrocytes and Schwann cells. These cells are unique in that they continue to arise in the olfactory epithelium from which they can migrate to the olfactory bulb throughout life [232-234]. Rodent and human OECs generate Schwann-cell-like myelin and improve conduction properties when transplanted to areas of demyelination in the brain or spinal cord [227, 233, 235-240]. OECs also have the capacity to promote axonal growth [241] and to secrete neurotrophic molecules [242, 243]. Thus, the relative availability of these cells, their apparent myelinating properties and their trophic effect on axonal growth make them another promising candidate for autologous therapeutic transplantation. It is not known whether OECs posess any immunologic properties.

\section{Non-Neural Stem Cells}

\section{Bone Marrow Stromal Cells}

BMSCs are nonhematopoietic mesenchymal stem cells that give rise to bone, tendon, and fat progeny. These type of cells burst into the regenerative neuroscience field with the suggestion that promiscuity of stem cells may allow them to transdifferentiate into mature cells of other tissues [244, 245]. Specifically, a number of investigators have reported that adult mouse and human BMSCs can differentiate in vitro into other cell types, including muscle, skin, liver, lung, and neural cells [246250]. It was also suggested that bone marrow-derived stromal cells can generate astrocytes [251], as wedll as produce myelin and remyelinate a demyelinated lesion of the spinal cord of the rat $[252,253]$. The potential of stromal cells for cell replacement therapy is still controversial in view of reports showing that stromal cells may rather fuse with existing neurons and glia, resulting in the formation of heterokaryons [248, 254]. Although the potential of BMSCs to remyelinate is controversial, a large volume of research has demonstrated their powerfull neurotrophic and immunomodulatory properties, as previously described. Thus, BMSCs may serve as an easily expandable, autologous source of cells with powerful therapeutic capabilities and probably a safe profile. These properties make them a good candidate for relatively straigtforward translation into clinical practice. 


\section{Route of Cell Delivery}

For a multi-focal disease like MS, the route of cell delivery becomes a primary consideration, raising 2 main questions: 1) what are the anatomic-biologic targets of cell therapy? The 2 main targets that may be contemplated include the white matter tracts, where immune-mediated demyelination should be halted and repair processes activated, and also the perivascular niche, where trafficking of immune cells occurs; and 2) to reach these targets, cell migration is crucial. Therefore, the cellular and environmental determinants of directed migration of transplanted cells into the proper sites need to be identified. Indeed, cell migration is a major limiting factor in endogenous remyelination. Intraventricular transplantation of various types of rodent precursor cells led to widespread myelination in the genetic dysmyelinating models of the shi mouse [143, 255] and the $m d$ rat [196]. Human oligodendrocyte progenitors showed similar capacity to disseminate white matter throughout the brain in these models [131]. However, in the lesioned adult CNS, there is limited migration of endogenous remyelinating cells resulting in local remyelination that may be insufficient for widespread lesions $[50,256]$.

The inflammatory process in the CNS of EAE animals was found to be a powerful stimulus stimulating subventricular PSA-NCAM+ cells $[56,57]$ and attracting targeted migration of transplanted neural and oligodendroglial precursor cells [94, 95, 257]. Following ICV transplantation of neurospheres, cells migrated into inflamed periventricular white matter tracts, and differentiated mainly into glial progeny. The greatest degree of migration occurred early in the course of disease [96], suggesting that transplantation may be optimally effective during a relatively narrow time window following the onset of an acute demyelinating episode. Importantly, transplanted precursors were found to possess superior migratory capabilities over endogenous precursors [81]. Thus, a major rationale for ICV route of cell delivery is that most white matter tracts that are involved in MS are in close proximity to the ventricular and spinal subarachnoid spaces. Following ICV injection, transplanted neural precursors may disseminate throughout the ventricular and subarachnoid space, enabling their inflammation-induced targeted migration into the white matter. By this, intraventricular and intrathecal transplantation may bring the remyelinating cells closest to the multiple foci of disease in MS without a separating barrier. Notably, when human embryonic stem cell-derived neural precursors were transplanted ICV, they also responded to inflammation by migration into the involved white matter tracts [96]. The observation that human neural precursors respond to tissue signals in an MS model in a very similar fashion to rodent cells is obviously indicative for the potential of clinical translation of cell therapy.
Various cytokines and growth factors, such as platelet derived growth factor [258, 259], fibroblast growth factor 2 [260], class 3 semaphorins [261, 262], Sonic hedgehog [263], stem cell factor [264], the chemokine stromal derived factor 1 (CXCL12) [265-269], epidermal growth factor [270], and vascular endothelial growth factor [271] increased the migration of progenitor cells of the oligodendrocyte or neuronal lineages in vitro, and were implicated in CNS development in vivo. Very little is known, however, on the molecular signals that control neural stem and progenitor cell migration in inflammation. In vitro studies showed that transforming growth factor- $\beta$ induces microglia to release hepatocyte growth factor, which increases OPC migration [98]. Tumor necrosis factor- $\alpha$ increased the motility of neural precursors in vitro [99]. Several chemokines were shown to be expressed in the inflamed brain [272]. Among these, stromal derived factor 1 was shown to induce neural stem/ precursor cells migration in stroke $[100,101]$, viralinduced demyelination [102], and trauma [103]. MCP-1 and its receptor CCR2 were shown to modulate neural precursor cell migration following cerebral ischemia [169]. In addition, injection of inflammatory stimuli in an ex vivo model of hippocampal slices attracted neural precursor depending of MCP-1 signaling via the CCR2 receptor [104].

Targeting the perivascular niche has been suggested mainly by the intravenous route of cell delivery from which the cells may cross the blood-brain-barrier [253, $273,274]$. The specific homing of NSCs to the brain was explained in part by the constitutive expression of a wide array of adhesion molecules (integrins, selectins, and so forth) and chemokine receptors by the transplanted cells [273, 275]. Integrins promote selective CNS homing through the interaction between transplanted cells and integrin receptor-expressing activated endothelial and ependymal cells surrounding inflamed brain tissues [276, 277]. Specifically, transendothelial migration was related to the expression of very late antigen-4 (VLA-4) and CD44 on NPCs, interacting with vascular cell adhesion molecule-1 (VCAM-1) and hyaluronic acid, respectively [173, 278]. This was shown to occur at a specific time window during the acute phase of EAE [273]. Recently, ICV transplanted NPCs were also shown to target the perivascular niche. Although cell migration was evident mostly in white matter tracts, cells also migrated in a radial fashion toward the cortex, along inflamed blood vessels [97]. Thus, transplanted NPCs may exhibit combined immunomodulatory, trophic, and regenerative properties in the involved white matter tracts, as well as at the perivascular spaces, which serve as junctions of inflammatory cell trafficking.

For the clinical application of BMSC transplantation, using their neurotrophic and immunomodulatory properties, 
similar targets should be considered, as discussed for neural precursors. BMSC can extravasate from the blood vessels into the tissue in a cell-adhesion molecule-dependent manner, similar to immune cells [279]. Therefore, intravenously administered BMSCs may arrive at the site of active disease in the inflamed CNS [194]. Alternatively, BMSCs can be delivered into the ventricular and subarachnoid space from which they inhibit EAE [195]. Several studies addressed the issue of BMSC migration within CNS tissue $[280,281]$, but it is not yet clear whether this occurs efficiently in EAE.

\section{When to Transplant}

In a chronic-relapsing disease like MS, timing of transplantation may be crucial, as cells that are introduced into the CNS during nonactive phases of the disease might not survive, whereas if they are introduced after the onset of relapse, it may be too late. The developing brain is highly permissive to transplanted neural stem and progenitor cells. In these circumstances, their target of migration and lineage fate are directed by the normal pattern of development at that stage. Accordingly, human multipotential NSCs that were transplanted into the embryonic rat brain generated mostly neurons [282], but when transplanted into the newborn brain, a stage in which neurogenesis is complete and gliogenesis is in action, the stem cells generated mostly glia [283]. In contrast, the adult CNS does not support the survival of transplanted cells [284]. Transplanted cells may integrate significantly better in acutely lesioned tissue. When oligodendrocyte progenitor cells were transplanted into the spinal cord of animals with experimental EAE and an ongoing inflammatory process, they survived much better in vivo [257]. It is not well understood what tissue factors support graft survival and integration, and that is an important direction of further basic research to develop improved cell transplantation strategies in chronic and degenerative brain conditions. One approach may be to promote self support of transplanted NSCs, independent of the CNS environment. It has been shown that in the form of spheres, NSCs may survive for a prolonged period of time both in vitro and in vivo in the lack of any exogenous growth factors [285]. After ICV transplantation, neurospheres survived for months in the ventricular space and retained their ability to migrate into the brain parenchyma in response to delayed induction of EAE. However, graft survival is also dependent also on it not being attacked by the autoimmune process or the host immune system in case of allogeneic transplantation. These issues are as yet unsolved, and in particular, whether or not the immunomodulatory properties of stem cells are sufficient to protect them from rejection.

\section{Clinical Translation}

Although clinical translation of neural/oligodendrocyte precursor cell therapy awaits the mass production of clinical grade cells with proven safety, BMSC therapy has already been implemented. Initial promising studies on the use of BMSC for improving hematopoietic stem cell transplantation and for prevention of graft versus host disease were not confirmed in controlled trials (for more details see Caimi et al. [286]). However, this clinical experience opened the way for a trial of BMSC transplantation in MS. As previously discussed, the rationale for BMSC therapy was to exploit their immunomodulatory and trophic properties in a CNStargeted manner. In a phase I/II open-safety clinical trial [287], BMSC were delivered intravenously and intrathecally into patients with chronic MS that had failed conventional treatments, and to patients with amyotrophic lateral sclerosis. There were transient side effects of headache and low grade fever, attributable to meningeal irritation, but no major side effects. Clinical follow-up showed that no patient worsened, and there was improvement in mean expanded disability score scale in the MS patients. Short-term immunological studies confirmed a systemic immunomodulatory effect of the intravenous treatment in these patients. Thus, we have entered an exciting new era of clinical experimentation of cell therapy in MS. Further studies are warranted to be able to define the efficacy of various cellular platforms, optimal dose, route of cell delivery, and timing of therapy.

Acknowledgements Full conflict of interest disclosure is available in the electronic supplementary material for this article.

\section{References}

1. Altman J, Das GD. Postnatal neurogenesis in the guinea-pig. Nature 1967;214:1098-1101.

2. Goldman SA, Nottebohm F. Neuronal production, migration, and differentiation in a vocal control nucleus of the adult female canary brain. Proc Natl Acad Sci U S A 1983;80:2390-2394.

3. Nottebohm F. Neuronal replacement in adulthood. Ann N Y Acad Sci $1985 ; 457: 143-161$.

4. Kirschenbaum B, Nedergaard M, Preuss A, Barami K, Fraser RA, Goldman SA. In vitro neuronal production and differentiation by precursor cells derived from the adult human forebrain. Cereb Cortex 1994;4:576-589.

5. Pincus DW, Keyoung HM, Harrison-Restelli C, et al. Fibroblast growth factor-2/brain-derived neurotrophic factor-associated maturation of new neurons generated from adult human subependymal cells. Ann Neurol 1998;43:576-585.

6. Eriksson PS, Perfilieva E, Bjork-Eriksson T, et al. Neurogenesis in the adult human hippocampus. Nat Med 1998;4:1313-1317.

7. Gritti A, Parati EA, Cova L, et al. Multipotential stem cells from the adult mouse brain proliferate and self-renew in response to basic fibroblast growth factor. J Neurosci 1996;16:1091-1100.

8. Reynolds BA, Weiss S. Generation of neurons and astrocytes from isolated cells of the adult mammalian central nervous system. Science 1992;255:1707-1710. 
9. Arsenijevic Y, Villemure JG, Brunet JF, et al. Isolation of multipotent neural precursors residing in the cortex of the adult human brain. Exp Neurol 2001;170:48-62.

10. Nunes MC, Roy NS, Keyoung HM, et al. Identification and isolation of multipotential neural progenitor cells from the subcortical white matter of the adult human brain. Nat Med 2003;9:439-447.

11. Ellis P, Fagan BM, Magness ST, et al. SOX2, a persistent marker for multipotential neural stem cells derived from embryonic stem cells, the embryo or the adult. Dev Neurosci 2004;26:148-165.

12. Schaffer DV, Gage FH. Neurogenesis and neuroadaptation. Neuromolecular Med 2004;5:1-9.

13. Picard-Riera N, Nait-Oumesmar B, Baron-Van Evercooren A. Endogenous adult neural stem cells: limits and potential to repair the injured central nervous system. J Neurosci Res 2004;76:223231.

14. Gritti A, Bonfanti L, Doetsch F, et al. Multipotent neural stem cells reside into the rostral extension and olfactory bulb of adult rodents. J Neurosci 2002;22:437-445.

15. Emsley JG, Mitchell BD, Kempermann G, Macklis JD. Adult neurogenesis and repair of the adult CNS with neural progenitors, precursors, and stem cells. Prog Neurobiol 2005;75:321-341.

16. Sohur US, Emsley JG, Mitchell BD, Macklis JD. Adult neurogenesis and cellular brain repair with neural progenitors, precursors and stem cells. Philos Trans R Soc Lond B Biol Sci 2006;361:1477-1497.

17. Lathia JD, Rao MS, Mattson MP, Ffrench-Constant C. The microenvironment of the embryonic neural stem cell: lessons from adult niches? Dev Dyn 2007;236:3267-3282.

18. Miller FD, Gauthier-Fisher A. Home at last: neural stem cell niches defined. Cell Stem Cell 2009;4:507-510.

19. Lois C, Garcia-Verdugo JM, Alvarez-Buylla A. Chain migration of neuronal precursors. Science 1996;271:978-981.

20. Garcia-Verdugo JM, Doetsch F, Wichterle H, Lim DA, Alvarez-Buylla A. Architecture and cell types of the adult subventricular zone: in search of the stem cells. J Neurobiol 1998;36:234-248.

21. Conover JC, Doetsch F, Garcia-Verdugo JM, Gale NW, Yancopoulos GD, Alvarez-Buylla A. Disruption of Eph/ephrin signaling affects migration and proliferation in the adult subventricular zone. Nat Neurosci 2000;3:1091-1097.

22. Pencea V, Bingaman KD, Freedman LJ, Luskin MB. Neurogenesis in the subventricular zone and rostral migratory stream of the neonatal and adult primate forebrain. Exp Neurol 2001;172:1-16.

23. De Marchis S, Fasolo A, Puche AC. Subventricular zone-derived neuronal progenitors migrate into the subcortical forebrain of postnatal mice. J Comp Neurol 2004;476:290-300.

24. Kuhn HG, Dickinson-Anson H, Gage FH. Neurogenesis in the dentate gyrus of the adult rat: age-related decrease of neuronal progenitor proliferation. J Neurosci 1996;16:2027-2033.

25. Altman J, Bayer SA. Migration and distribution of two populations of hippocampal granule cell precursors during the perinatal and postnatal periods. J Comp Neurol 1990;301:365-381.

26. Kaplan MS, Hinds JW. Neurogenesis in the adult rat: electron microscopic analysis of light radioautographs. Science 1977;197:1092-1094.

27. Palmer TD, Ray J, Gage FH. FGF-2-responsive neuronal progenitors reside in proliferative and quiescent regions of the adult rodent brain. Mol Cell Neurosci 1995;6:474-486.

28. Roy NS, Wang S, Jiang L, et al. In vitro neurogenesis by progenitor cells isolated from the adult human hippocampus. Nat Med 2000;6:271-277.
29. Doetsch F, Caille I, Lim DA, Garcia-Verdugo JM, AlvarezBuylla A. Subventricular zone astrocytes are neural stem cells in the adult mammalian brain. Cell 1999;97:703-716.

30. Meletis K, Barnabe-Heider F, Carlen M, et al. Spinal cord injury reveals multilineage differentiation of ependymal cells. PLoS Biol 2008;6:e182.

31. Morshead CM, Reynolds BA, Craig CG, et al. Neural stem cells in the adult mammalian forebrain: a relatively quiescent subpopulation of subependymal cells. Neuron 1994;13:1071-1082.

32. Kirschenbaum B, Goldman SA. Brain-derived neurotrophic factor promotes the survival of neurons arising from the adult rat forebrain subependymal zone. Proc Natl Acad Sci U S A 1995;92:210-214.

33. Ahmed S, Reynolds BA, Weiss S. BDNF enhances the differentiation but not the survival of CNS stem cell-derived neuronal precursors. J Neurosci 1995;15:5765-5778.

34. Palmer TD, Markakis EA, Willhoite AR, Safar F, Gage FH. Fibroblast growth factor-2 activates a latent neurogenic program in neural stem cells from diverse regions of the adult CNS. J Neurosci 1999;19:8487-8497.

35. Wolswijk G, Noble M. Identification of an adult-specific glial progenitor cell. Development 1989;105:387-400.

36. Milner R, Anderson HJ, Rippon RF, et al. Contrasting effects of mitogenic growth factors on oligodendrocyte precursor cell migration. Glia 1997;19:85-90.

37. Dawson MR, Polito A, Levine JM, Reynolds R. NG2-expressing glial progenitor cells: an abundant and widespread population of cycling cells in the adult rat CNS. Mol Cell Neurosci 2003;24:476-488.

38. Scolding NJ, Rayner PJ, Sussman J, Shaw C, Compston DA. A proliferative adult human oligodendrocyte progenitor. Neuroreport 1995;6:441-445.

39. Scolding N, Franklin R, Stevens S, Heldin CH, Compston A, Newcombe J. Oligodendrocyte progenitors are present in the normal adult human CNS and in the lesions of multiple sclerosis. Brain 1998;121:2221-2228.

40. Roy NS, Wang S, Harrison-Restelli C, et al. Identification, isolation, and promoter-defined separation of mitotic oligodendrocyte progenitor cells from the adult human subcortical white matter. J Neurosci 1999;19:9986-9995.

41. Horner PJ, Thallmair M, Gage FH. Defining the NG2-expressing cell of the adult CNS. J Neurocytol 2002;31:469-480.

42. Windrem MS, Nunes MC, Rashbaum WK, et al. Fetal and adult human oligodendrocyte progenitor cell isolates myelinate the congenitally dysmyelinated brain. Nat Med 2004;10:93-97.

43. Horner PJ, Power AE, Kempermann G, et al. Proliferation and differentiation of progenitor cells throughout the intact adult rat spinal cord. J Neurosci 2000;20:2218-2228.

44. Franklin RJ, Ffrench-Constant C. Remyelination in the CNS: from biology to therapy. Nat Rev Neurosci 2008;9:839-855.

45. Wolswijk G. Oligodendrocyte survival, loss and birth in lesions of chronic-stage multiple sclerosis. Brain 2000;123:105-115.

46. Wolswijk G. Oligodendrocyte precursor cells in the demyelinated multiple sclerosis spinal cord. Brain 2002;125:338-349.

47. Keirstead HS, Blakemore WF. Identification of post-mitotic oligodendrocytes incapable of remyelination within the demyelinated adult spinal cord. J Neuropathol Exp Neurol 1997;56:1191-1201.

48. Targett MP, Sussman J, Scolding N, O'Leary MT, Compston DA, Blakemore WF. Failure to achieve remyelination of demyelinated rat axons following transplantation of glial cells obtained from the adult human brain. Neuropathol Appl Neurobiol 1996;22:199-206.

49. Frost EE, Nielsen JA, Le TQ, Armstrong RC. PDGF and FGF2 regulate oligodendrocyte progenitor responses to demyelination. J Neurobiol 2003;54:457-472. 
50. Gensert JM, Goldman JE. Endogenous progenitors remyelinate demyelinated axons in the adult CNS. Neuron 1997;19:197-203.

51. Redwine JM, Armstrong RC. In vivo proliferation of oligodendrocyte progenitors expressing PDGFalphaR during early remyelination. J Neurobiol 1998;37:413-428.

52. Keirstead HS, Blakemore WF. The role of oligodendrocytes and oligodendrocyte progenitors in CNS remyelination. Adv Exp Med Biol 1999;468:183-197.

53. Di Bello IC, Dawson MR, Levine JM, Reynolds R. Generation of oligodendroglial progenitors in acute inflammatory demyelinating lesions of the rat brain stem is associated with demyelination rather than inflammation. J Neurocytol 1999;28:365-381.

54. Zawadzka M, Rivers LE, Fancy SP, et al. CNS-resident glial progenitor/stem cells produce Schwann cells as well as oligodendrocytes during repair of CNS demyelination. Cell Stem Cell 2010;6:578-590.

55. Tripathi RB, Rivers LE, Young KM, Jamen F, Richardson WD. NG2 glia generate new oligodendrocytes but few astrocytes in a murine experimental autoimmune encephalomyelitis model of demyelinating disease. J Neurosci 2010;30:1638316390.

56. Nait-Oumesmar B, Decker L, Lachapelle F, Avellana-Adalid V, Bachelin C, Van Evercooren AB. Progenitor cells of the adult mouse subventricular zone proliferate, migrate and differentiate into oligodendrocytes after demyelination. Eur J Neurosci 1999;11:4357-4366.

57. Picard-Riera ND, L. Delarasse, C. Goude, K. Nait-Oumesmar, B. Liblau, R. Pham-Dinh, D. Evercooren, AB. Experimental autoimmune encephalomyelitis mobilizes neural progenitors from the subventricular zone to undergo oligodendrogenesis in adult mice. Proceedings of the National Academy of Sciences USA 2002;99:13211-13216.

58. Menn B, Garcia-Verdugo JM, Yaschine C, Gonzalez-Perez O, Rowitch D, Alvarez-Buylla A. Origin of oligodendrocytes in the subventricular zone of the adult brain. J Neurosci 2006;26:79077918.

59. Aguirre A, Dupree JL, Mangin JM, Gallo V. A functional role for EGFR signaling in myelination and remyelination. Nat Neurosci 2007;10:990-1002.

60. Prineas JW, Barnard RO, Kwon EE, Sharer LR, Cho ES. Multiple sclerosis: remyelination of nascent lesions. Ann Neurol 1993;33:137-151.

61. Raine CS, Wu E. Multiple sclerosis: remyelination in acute lesions. J Neuropathol Exp Neurol 1993;52:199-204.

62. Compston A. Remyelination of the central nervous system. Mult Scler 1996;1:388-392.

63. Barkhof F, Bruck W, De Groot CJ, et al. Remyelinated lesions in multiple sclerosis: magnetic resonance image appearance. Arch Neurol 2003;60:1073-1081.

64. Lucchinetti C, Bruck W, Parisi J, Scheithauer B, Rodriguez M, Lassmann H. Heterogeneity of multiple sclerosis lesions: implications for the pathogenesis of demyelination. Ann Neurol 2000; 47:707-717

65. Lucchinetti C, Bruck W, Parisi J, Scheithauer B, Rodriguez M, Lassmann $\mathrm{H}$. A quantitative analysis of oligodendrocytes in multiple sclerosis lesions. A study of 113 cases. Brain 1999;122:2279-2295.

66. Blakemore WF, Chari DM, Gilson JM, Crang AJ. Modelling large areas of demyelination in the rat reveals the potential and possible limitations of transplanted glial cells for remyelination in the CNS. Glia 2002;38:155-168.

67. Franklin RJ. Why does remyelination fail in multiple sclerosis? Nat Rev Neurosci 2002;3:705-714.

68. De Stefano N, Matthews PM, Fu L, et al. Axonal damage correlates with disability in patients with relapsing- remitting multiple sclerosis. Results of a longitudinal magnetic resonance spectroscopy study. Brain 1998;121:1469-1477.

69. Bjartmar C, Yin X, Trapp BD. Axonal pathology in myelin disorders. J Neurocytol 1999;28:383-395.

70. Steinman L. Multiple sclerosis: a two-stage disease. Nat Immunol 2001;2:762-764.

71. Hemmer B, Archelos JJ, Hartung HP. New concepts in the immunopathogenesis of multiple sclerosis. Nat Rev Neurosci 2002;3:291-301.

72. Bjartmar C, Kidd G, Mork S, Rudick R, Trapp BD. Neurological disability correlates with spinal cord axonal loss and reduced $\mathrm{N}$-acetyl aspartate in chronic multiple sclerosis patients. Ann Neurol 2000;48:893-901.

73. Wujek JR, Bjartmar C, Richer E, et al. Axon loss in the spinal cord determines permanent neurological disability in an animal model of multiple sclerosis. J Neuropathol Exp Neurol 2002;61:23-32.

74. Mason JL, Toews A, Hostettler JD, et al. Oligodendrocytes and progenitors become progressively depleted within chronically demyelinated lesions. Am J Pathol 2004;164:1673-1682.

75. Penderis J, Shields SA, Franklin RJ. Impaired remyelination and depletion of oligodendrocyte progenitors does not occur following repeated episodes of focal demyelination in the rat central nervous system. Brain 2003;126:1382-1391.

76. Wolswijk G. Chronic stage multiple sclerosis lesions contain a relatively quiescent population of oligodendrocyte precursor cells. J Neurosci 1998;18:601-609.

77. Chang A, Nishiyama A, Peterson J, Prineas J, Trapp BD. NG2positive oligodendrocyte progenitor cells in adult human brain and multiple sclerosis lesions. J Neurosci 2000;20:6404-6412.

78. Chang A, Tourtellotte WW, Rudick R, Trapp BD. Premyelinating oligodendrocytes in chronic lesions of multiple sclerosis. N Engl J Med 2002;346:165-173.

79. Sim FJ, Zhao C, Penderis J, Franklin RJ. The age-related decrease in CNS remyelination efficiency is attributable to an impairment of both oligodendrocyte progenitor recruitment and differentiation. J Neurosci 2002;22:2451-2459.

80. Shen S, Sandoval J, Swiss VA, et al. Age-dependent epigenetic control of differentiation inhibitors is critical for remyelination efficiency. Nat Neurosci. 2008 11(9):1024-34.

81. Blakemore WF, Gilson JM, Crang AJ. Transplanted glial cells migrate over a greater distance and remyelinate demyelinated lesions more rapidly than endogenous remyelinating cells. J Neurosci Res 2000;61:288-294.

82. Psachoulia K, Jamen F, Young KM, Richardson WD. Cell cycle dynamics of NG2 cells in the postnatal and ageing brain. Neuron Glia Biol 2009;5:57-67.

83. Wolswijk G, Noble M. Cooperation between PDGF and FGF converts slowly dividing O-2Aadult progenitor cells to rapidly dividing cells with characteristics of O-2Aperinatal progenitor cells. J Cell Biol 1992;118:889-900.

84. Trapp BD, Peterson J, Ransohoff RM, Rudick R, Mork S, Bo L. Axonal transection in the lesions of multiple sclerosis. N Engl J Med 1998;338:278-285.

85. John GR, Shankar SL, Shafit-Zagardo B, et al. Multiple sclerosis: re-expression of a developmental pathway that restricts oligodendrocyte maturation. Nat Med 2002;8:11151121.

86. Stidworthy MF, Genoud S, Li WW, et al. Notch1 and Jagged1 are expressed after CNS demyelination, but are not a major ratedetermining factor during remyelination. Brain 2004;127:19281941.

87. Nakahara J, Kanekura K, Nawa M, Aiso S, Suzuki N. Abnormal expression of TIP30 and arrested nucleocytoplasmic transport within oligodendrocyte precursor cells in multiple sclerosis. J Clin Invest 2009;119:169-181. 
88. Raff MC, Lillien LE, Richardson WD, Burne JF, Noble MD. Platelet-derived growth factor from astrocytes drives the clock that times oligodendrocyte development in culture. Nature 1988;333:562-565.

89. Vana AC, Flint NC, Harwood NE, Le TQ, Fruttiger M, Armstrong RC. Platelet-derived growth factor promotes repair of chronically demyelinated white matter. J Neuropathol Exp Neurol 2007;66:975-988.

90. Woodruff RH, Fruttiger M, Richardson WD, Franklin RJ. Platelet-derived growth factor regulates oligodendrocyte progenitor numbers in adult CNS and their response following CNS demyelination. Mol Cell Neurosci 2004;25:252-262.

91. Brinkmann BG, Agarwal A, Sereda MW, et al. Neuregulin-1/ ErbB signaling serves distinct functions in myelination of the peripheral and central nervous system. Neuron 2008;59:581595.

92. Machold R, Hayashi S, Rutlin M, et al. Sonic hedgehog is required for progenitor cell maintenance in telencephalic stem cell niches. Neuron 2003;39:937-950.

93. Palma V, Lim DA, Dahmane N, et al. Sonic hedgehog controls stem cell behavior in the postnatal and adult brain. Development 2005;132:335-344.

94. Ben-Hur T, Einstein O, Mizrachi-Kol R, et al. Transplanted multipotential neural precursor cells migrate into the inflamed white matter in response to experimental autoimmune encephalomyelitis. Glia 2003;41:73-80.

95. Bulte JW, Ben-Hur T, Miller BR, et al. MR microscopy of magnetically labeled neurospheres transplanted into the Lewis EAE rat brain. Magn Reson Med 2003;50:201-205.

96. Ben-Hur T, van Heeswijk RB, Einstein O, et al. Serial in vivo MR tracking of magnetically labeled neural spheres transplanted in chronic EAE mice. Magn Reson Med 2007;57:164-171.

97. Muja N, Cohen ME, Zhang J, et al. Neural precursors exhibit distinctly different patterns of cell migration upon transplantation during either the acute or chronic phase of EAE: A serial MR imaging study. Magn Reson Med. 2011 65(6):1738-49.

98. Lalive PH, Paglinawan R, Biollaz G, et al. TGF-beta-treated microglia induce oligodendrocyte precursor cell chemotaxis through the HGF-c-Met pathway. Eur J Immunol 2005;35:727-737.

99. Ben-Hur T, Ben-Menachem O, Furer V, Einstein O, Mizrachi-Kol $\mathrm{R}$, Grigoriadis N. Effects of proinflammatory cytokines on the growth, fate, and motility of multipotential neural precursor cells. Mol Cell Neurosci 2003;24:623-631.

100. Imitola J, Raddassi K, Park KI, et al. Directed migration of neural stem cells to sites of CNS injury by the stromal cellderived factor $1 \mathrm{alpha} / \mathrm{CXC}$ chemokine receptor 4 pathway. Proc Natl Acad Sci U S A 2004;101:18117-18122.

101. Robin AM, Zhang ZG, Wang L, et al. Stromal cell-derived factor 1alpha mediates neural progenitor cell motility after focal cerebral ischemia. J Cereb Blood Flow Metab 2006;26:125-134.

102. Carbajal KS, Schaumburg C, Strieter R, Kane J, Lane TE. Migration of engrafted neural stem cells is mediated by CXCL12 signaling through CXCR4 in a viral model of multiple sclerosis. Proc Natl Acad Sci U S A 2010;107:11068-11073.

103. Itoh $\mathrm{T}$, Satou $\mathrm{T}$, Ishida $\mathrm{H}$, et al. The relationship between SDF-1alpha/CXCR4 and neural stem cells appearing in damaged area after traumatic brain injury in rats. Neurol Res 2009;31:90-102

104. Belmadani A, Tran PB, Ren D, Miller RJ. Chemokines regulate the migration of neural progenitors to sites of neuroinflammation. J Neurosci 2006;26:3182-3191.

105. Foote AK, Blakemore WF. Inflammation stimulates remyelination in areas of chronic demyelination. Brain 2005;128:528-539.

106. Setzu A, Lathia JD, Zhao $\mathrm{C}$, et al. Inflammation stimulates myelination by transplanted oligodendrocyte precursor cells. Glia 2006;54:297-303.
107. Stankoff B, Aigrot MS, Noel F, Wattilliaux A, Zalc B, Lubetzki C. Ciliary neurotrophic factor (CNTF) enhances myelin formation: a novel role for CNTF and CNTF-related molecules. J Neurosci 2002;22:9221-9227.

108. Baer AS, Syed YA, Kang SU, et al. Myelin-mediated inhibition of oligodendrocyte precursor differentiation can be overcome by pharmacological modulation of Fyn-RhoA and protein kinase C signalling. Brain 2009;132:465-481.

109. Mi S, Hu B, Hahm K, et al. LINGO-1 antagonist promotes spinal cord remyelination and axonal integrity in MOG-induced experimental autoimmune encephalomyelitis. Nat Med 2007;13:1228-1233.

110. Mi S, Miller RH, Tang W, et al. Promotion of central nervous system remyelination by induced differentiation of oligodendrocyte precursor cells. Ann Neurol 2009;65:304-315.

111. Miron VE, Rajasekharan S, Jarjour AA, Zamvil SS, Kennedy TE, Antel JP. Simvastatin regulates oligodendroglial process dynamics and survival. Glia 2007;55:130-143.

112. Sim FJ, Lang JK, Ali TA, et al. Statin treatment of adult human glial progenitors induces PPAR gamma-mediated oligodendrocytic differentiation. Glia 2008;56:954-962.

113. Miron VE, Zehntner SP, Kuhlmann T, et al. Statin therapy inhibits remyelination in the central nervous system. Am J Pathol 2009;174:1880-1890.

114. Arnett HA, Fancy SP, Alberta JA, et al. bHLH transcription factor Olig1 is required to repair demyelinated lesions in the CNS. Science 2004;306:2111-2115.

115. Huang JK, Jarjour AA, Nait Oumesmar B, et al. Retinoid X receptor gamma signaling accelerates CNS remyelination. Nat Neurosci 2011;14:45-53.

116. Fancy SP, Baranzini SE, Zhao C, et al. Dysregulation of the Wnt pathway inhibits timely myelination and remyelination in the mammalian CNS. Genes Dev 2009;23:1571-1585.

117. Caillava C, Vandenbosch R, Jablonska B, et al. Cdk2 loss accelerates precursor differentiation and remyelination in the adult central nervous system. J Cell Biol 2011;193:397-407.

118. Goldman SA, Schanz S, Windrem MS. Stem cell-based strategies for treating pediatric disorders of myelin. Hum Mol Genet 2008; 17:R76-83.

119. Ben-Hur T, Goldman SA. Prospects of cell therapy for disorders of myelin. Ann N Y Acad Sci 2008;1142:218-249.

120. Yang J, Rostami A, Zhang GX. Cellular remyelinating therapy in multiple sclerosis. J Neurol Sci 2009;276:1-5.

121. Miron VE, Kuhlmann T, Antel JP. Cells of the oligodendroglial lineage, myelination, and remyelination. Biochim Biophys Acta; 1812:184-193.

122. Martino G, Franklin RJ, Van Evercooren AB, Kerr DA. Stem cell transplantation in multiple sclerosis: current status and future prospects. Nat Rev Neurol 2010;6:247-255.

123. Crang AJ, Gilson J, Blakemore WF. The demonstration by transplantation of the very restricted remyelinating potential of post-mitotic oligodendrocytes. J Neurocytol 1998;27:541-553.

124. Groves AK, Barnett SC, Franklin RJ, et al. Repair of demyelinated lesions by transplantation of purified O-2A progenitor cells. Nature 1993;362:453-455.

125. Warrington AE, Barbarese E, Pfeiffer SE. Differential myelinogenic capacity of specific developmental stages of the oligodendrocyte lineage upon transplantation into hypomyelinating hosts. J Neurosci Res 1993;34:1-13.

126. Archer DR, Cuddon PA, Lipsitz D, Duncan ID. Myelination of the canine central nervous system by glial cell transplantation: a model for repair of human myelin disease. Nat Med 1997;3:54-59.

127. Windrem MS, Roy NS, Wang J, et al. Progenitor cells derived from the adult human subcortical white matter disperse and differentiate as oligodendrocytes within demyelinated lesions of the rat brain. J Neurosci Res 2002;69:966-975. 
128. Utzschneider DA, Archer DR, Kocsis JD, Waxman SG, Duncan ID. Transplantation of glial cells enhances action potential conduction of amyelinated spinal cord axons in the myelin-deficient rat. Proc Natl Acad Sci U S A 1994;91:5357.

129. Buchet D, Garcia C, Deboux C, Nait-Oumesmar B, Baron-Van Evercooren A. Human neural progenitors from different foetal forebrain regions remyelinate the adult mouse spinal cord. Brain 2011;134:1168-1183.

130. Readhead C, Hood L. The dysmyelinating mouse mutations shiverer (shi) and myelin deficient (shimld). Behav Genet 1990;20:213-234.

131. Windrem MS, Schanz SJ, Guo M, et al. Neonatal chimerization with human glial progenitor cells can both remyelinate and rescue the otherwise lethally hypomyelinated shiverer mouse. Cell Stem Cell 2008;2:553-565

132. Keyoung HM, Roy NS, Benraiss A, et al. High-yield selection and extraction of two promoter-defined phenotypes of neural stem cells from the fetal human brain. Nat Biotechnol 2001;19:843-850.

133. Gritti A, Frolichsthal-Schoeller P, Galli R, et al. Epidermal and fibroblast growth factors behave as mitogenic regulators for a single multipotent stem cell-like population from the subventricular region of the adult mouse forebrain. J Neurosci 1999;19:3287-3297.

134. Grinspan JB, Franceschini B. Platelet-derived growth factor is a survival factor for PSA-NCAM+ oligodendrocyte pre-progenitor cells. J Neurosci Res 1995;41:540-551.

135. Ben-Hur T, Rogister B, Murray K, Rougon G, Dubois-Dalcq M. Growth and fate of PSA-NCAM+ precursors of the postnatal brain. J Neurosci 1998;18:5777-5788

136. Mayer-Proschel M, Kalyani AJ, Mujtaba T, Rao MS. Isolation of lineage-restricted neuronal precursors from multipotent neuroepithelial stem cells. Neuron 1997;19:773-785.

137. Kleene R, Schachner M. Glycans and neural cell interactions. Nat Rev Neurosci 2004;5:195-208.

138. Vitry S, Avellana-Adalid V, Hardy R, Lachapelle F, BaronVan Evercooren A. Mouse oligospheres: from pre-progenitors to functional oligodendrocytes. J Neurosci Res 1999;58:735751.

139. Decker L, Avellana-Adalid V, Nait-Oumesmar B, Durbec P, Baron-Van Evercooren A. Oligodendrocyte precursor migration and differentiation: combined effects of PSA residues, growth factors, and substrates. Mol Cell Neurosci 2000;16:422-439.

140. Vitry S, Avellana-Adalid V, Lachapelle F, Evercooren AB. Migration and multipotentiality of PSA-NCAM+ neural precursors transplanted in the developing brain. Mol Cell Neurosci 2001;17:983-1000.

141. Keirstead HS, Ben-Hur T, Rogister B, O'Leary MT, DuboisDalcq M, Blakemore WF. Polysialylated neural cell adhesion molecule-positive CNS precursors generate both oligodendrocytes and Schwann cells to remyelinate the CNS after transplantation. J Neurosci 1999;19:7529-7536.

142. Akiyama Y, Honmou O, Kato T, Uede T, Hashi K, Kocsis JD. Transplantation of clonal neural precursor cells derived from adult human brain establishes functional peripheral myelin in the rat spinal cord. Exp Neurol 2001;167:27-39.

143. Yandava BD, Billinghurst LL, Snyder EY. "Global" cell replacement is feasible via neural stem cell transplantation: evidence from the dysmyelinated shiverer mouse brain. Proc Natl Acad Sci U S A 1999;96:7029-7034.

144. Hammang JP, Archer DR, Duncan ID. Myelination following transplantation of EGF-responsive neural stem cells into a myelin-deficient environment. Exp Neurol 1997;147:84-95.

145. Milward EA, Lundberg CG, Ge B, Lipsitz D, Zhao M, Duncan ID. Isolation and transplantation of multipotential populations of epidermal growth factor-responsive, neural progenitor cells from the canine brain. J Neurosci Res 1997;50:862-871.

146. Cummings BJ, Uchida N, Tamaki SJ, et al. Human neural stem cells differentiate and promote locomotor recovery in spinal cord-injured mice. Proc Natl Acad Sci U S A 2005;102:1406914074

147. Karimi-Abdolrezaee S, Eftekharpour E, Wang J, Morshead CM, Fehlings MG. Delayed transplantation of adult neural precursor cells promotes remyelination and functional neurological recovery after spinal cord injury. J Neurosci 2006;26:3377-3389.

148. Ludwin SK. Central nervous system demyelination and remyelination in the mouse: an ultrastructural study of cuprizone toxicity. Lab Invest 1978;39:597-612.

149. Blakemore WF. Ethidium bromide induced demyelination in the spinal cord of the cat. Neuropathol Appl Neurobiol 1982;8:365375 .

150. Waxman SG, Kocsis JD, Nitta KC. Lysophosphatidyl choline-induced focal demyelination in the rabbit corpus callosum. Light-microscopic observations. J Neurol Sci 1979;44:45-53.

151. Aharonowiz M, Einstein O, Fainstein N, Lassmann H, Reubinoff B, Ben-Hur T. Neuroprotective effect of transplanted human embryonic stem cell-derived neural precursors in an animal model of multiple sclerosis. PLoS ONE 2008;3:e3145.

152. Martino G, Pluchino S. The therapeutic potential of neural stem cells. Nat Rev Neurosci 2006;7:395-406.

153. Teng YD, Lavik EB, Qu X, et al. Functional recovery following traumatic spinal cord injury mediated by a unique polymer scaffold seeded with neural stem cells. Proc Natl Acad Sci U S A 2002;99:3024-3029.

154. Park KI, Teng YD, Snyder EY. The injured brain interacts reciprocally with neural stem cells supported by scaffolds to reconstitute lost tissue. Nat Biotechnol 2002;20:1111-1117.

155. Capone C, Frigerio S, Fumagalli S, et al. Neurosphere-derived cells exert a neuroprotective action by changing the ischemic microenvironment. PLoS ONE 2007;2:e373.

156. Ourednik J, Ourednik V, Lynch WP, Schachner M, Snyder EY. Neural stem cells display an inherent mechanism for rescuing dysfunctional neurons. Nat Biotechnol 2002;20:1103-1110.

157. Ferrer-Alcon M, Winkler-Hirt C, Perrin FE, Kato AC. Grafted neural stem cells increase the life span and protect motoneurons in pmn mice. Neuroreport 2007;18:1463-1468.

158. Kerr DA, Llado J, Shamblott MJ, et al. Human embryonic germ cell derivatives facilitate motor recovery of rats with diffuse motor neuron injury. J Neurosci 2003;23:5131-5140.

159. Suzuki M, McHugh J, Tork C, et al. GDNF secreting human neural progenitor cells protect dying motor neurons, but not their projection to muscle, in a rat model of familial ALS. PLoS ONE 2007;2:e689.

160. Einstein O, Ben-Hur T. The changing face of neural stem cell therapy in neurologic diseases. Arch Neurol 2008;65:452-456.

161. Kumagai G, Okada Y, Yamane J, et al. Roles of ES cell-derived gliogenic neural stem/progenitor cells in functional recovery after spinal cord injury. PLoS ONE 2009;4:e7706.

162. Lu P, Jones LL, Snyder EY, Tuszynski MH. Neural stem cells constitutively secrete neurotrophic factors and promote extensive host axonal growth after spinal cord injury. Exp Neurol 2003;181:115-129.

163. Zhang Y, Klassen HJ, Tucker BA, Perez MT, Young MJ. CNS progenitor cells promote a permissive environment for neurite outgrowth via a matrix metalloproteinase-2-dependent mechanism. J Neurosci 2007;27:4499-4506.

164. Pfeifer K, Vroemen M, Blesch A, Weidner N. Adult neural progenitor cells provide a permissive guiding substrate for corticospinal axon growth following spinal cord injury. Eur J Neurosci 2004;20:1695-1704 
165. Rauch MF, Hynes SR, Bertram J, et al. Engineering angiogenesis following spinal cord injury: a coculture of neural progenitor and endothelial cells in a degradable polymer implant leads to an increase in vessel density and formation of the blood-spinal cord barrier. Eur J Neurosci 2009;29:132-145.

166. Keirstead HS, Nistor G, Bernal G, et al. Human embryonic stem cell-derived oligodendrocyte progenitor cell transplants remyelinate and restore locomotion after spinal cord injury. J Neurosci 2005;25:4694-4705.

167. Hattiangady B, Shuai B, Cai J, Coksaygan T, Rao MS, Shetty AK. Increased dentate neurogenesis after grafting of glial restricted progenitors or neural stem cells in the aging hippocampus. Stem Cells 2007;25:2104-2117.

168. Ben Menachem-Zidon O, Avital A, Ben-Menahem Y, et al. Astrocytes support hippocampal-dependent memory and longterm potentiation via interleukin-1 signaling. Brain Behav Immun 2010.

169. Ben-Shaanan TL, Ben-Hur T, Yanai J. Transplantation of neural progenitors enhances production of endogenous cells in the impaired brain. Mol Psychiatry 2008;13:222-231.

170. Einstein O, Friedman-Levi Y, Grigoriadis N, Ben-Hur T. Transplanted neural precursors enhance host brain-derived myelin regeneration. J Neurosci 2009;29:15694-15702.

171. Einstein O, Karussis D, Grigoriadis N, et al. Intraventricular transplantation of neural precursor cell spheres attenuates acute experimental allergic encephalomyelitis. Mol Cell Neurosci 2003;24:1074-1082.

172. Swanborg RH. Experimental autoimmune encephalomyelitis in the rat: lessons in T-cell immunology and autoreactivity. Immunol Rev 2001;184:129-135.

173. Pluchino S, Zanotti L, Rossi B, et al. Neurosphere-derived multipotent precursors promote neuroprotection by an immunomodulatory mechanism. Nature 2005;436:266-271.

174. Einstein O, Grigoriadis N, Mizrachi-Kol R, et al. Transplanted neural precursor cells reduce brain inflammation to attenuate chronic experimental autoimmune encephalomyelitis. Exp Neurol 2006;198:275-284.

175. Pluchino S, Gritti A, Blazer E, et al. Human neural stem cells ameliorate autoimmune encephalomyelitis in non human primates. Ann Neurol 2009;66:343-354.

176. Ben-Hur T. Immunomodulation by neural stem cells. J Neurol Sci 2008;265:102-104.

177. Einstein O, Fainstein N, Vaknin I, et al. Neural precursors attenuate autoimmune encephalomyelitis by peripheral immunosuppression. Ann Neurol 2007;61:209-218.

178. Lee ST, Chu K, Jung KH, et al. Anti-inflammatory mechanism of intravascular neural stem cell transplantation in haemorrhagic stroke. Brain 2008;131:616-629.

179. Fainstein N, Vaknin I, Einstein O, et al. Neural precursor cells inhibit multiple inflammatory signals. Mol Cell Neurosci 2008;39:335-341.

180. Pluchino S, Zanotti L, Brambilla E, et al. Immune regulatory neural stem/precursor cells protect from central nervous system autoimmunity by restraining dendritic cell function. PLoS ONE 2009;4:e5959.

181. Muguruma Y, Yahata T, Miyatake H, et al. Reconstitution of the functional human hematopoietic microenvironment derived from human mesenchymal stem cells in the murine bone marrow compartment. Blood 2006;107:1878-1887.

182. Pittenger MF, Mackay AM, Beck SC, et al. Multilineage potential of adult human mesenchymal stem cells. Science 1999;284:143-147.

183. Andrews EM, Tsai SY, Johnson SC, et al. Human adult bone marrow-derived somatic cell therapy results in functional recovery and axonal plasticity following stroke in the rat. Exp Neurol 2008;211:588-592.
184. Ankeny DP, McTigue DM, Jakeman LB. Bone marrow transplants provide tissue protection and directional guidance for axons after contusive spinal cord injury in rats. Exp Neurol 2004;190:17-31.

185. Jiang XX, Zhang Y, Liu B, et al. Human mesenchymal stem cells inhibit differentiation and function of monocyte-derived dendritic cells. Blood 2005;105:4120-4126.

186. Beyth S, Borovsky Z, Mevorach D, et al. Human mesenchymal stem cells alter antigen-presenting cell maturation and induce Tcell unresponsiveness. Blood 2005;105:2214-2219.

187. Ramasamy R, Fazekasova H, Lam EW, Soeiro I, Lombardi G, Dazzi F. Mesenchymal stem cells inhibit dendritic cell differentiation and function by preventing entry into the cell cycle. Transplantation 2007;83:71-76.

188. Di Nicola M, Carlo-Stella C, Magni M, et al. Human bone marrow stromal cells suppress T-lymphocyte proliferation induced by cellular or nonspecific mitogenic stimuli. Blood 2002;99:38383843.

189. Glennie S, Soeiro I, Dyson PJ, Lam EW, Dazzi F. Bone marrow mesenchymal stem cells induce division arrest anergy of activated T cells. Blood 2005;105:2821-2827.

190. Aggarwal S, Pittenger MF. Human mesenchymal stem cells modulate allogeneic immune cell responses. Blood 2005;105:1815-1822.

191. Corcione A, Benvenuto F, Ferretti E, et al. Human mesenchymal stem cells modulate B-cell functions. Blood 2006;107:367-372.

192. Uccelli A, Moretta L, Pistoia V. Mesenchymal stem cells in health and disease. Nat Rev Immunol 2008;8:726-736.

193. Zappia E, Casazza S, Pedemonte E, et al. Mesenchymal stem cells ameliorate experimental autoimmune encephalomyelitis inducing T-cell anergy. Blood 2005;106:1755-1761.

194. Gerdoni E, Gallo B, Casazza S, et al. Mesenchymal stem cells effectively modulate pathogenic immune response in experimental autoimmune encephalomyelitis. Ann Neurol 2007;61:219227.

195. Kassis I, Grigoriadis N, Gowda-Kurkalli B, et al. Neuroprotection and immunomodulation with mesenchymal stem cells in chronic experimental autoimmune encephalomyelitis. Arch Neurol 2008;65:753-761.

196. Brustle O, Jones KN, Learish RD, et al. Embryonic stem cellderived glial precursors: a source of myelinating transplants. Science 1999;285:754-756.

197. Liu S, Qu Y, Stewart TJ, et al. Embryonic stem cells differentiate into oligodendrocytes and myelinate in culture and after spinal cord transplantation. Proc Natl Acad Sci U S A 2000;97:61266131.

198. Billon N, Jolicoeur C, Ying QL, Smith A, Raff M. Normal timing of oligodendrocyte development from genetically engineered, lineage-selectable mouse ES cells. J Cell Sci 2002;115:3657-3665.

199. Thomson JA, Itskovitz-Eldor J, Shapiro SS, et al. Embryonic stem cell lines derived from human blastocysts. Science 1998;282:1145-1147.

200. Reubinoff BE, Pera MF, Fong CY, Trounson A, Bongso A. Embryonic stem cell lines from human blastocysts: somatic differentiation in vitro. Nat Biotechnol 2000;18:399-404.

201. Reubinoff BE, Itsykson P, Turetsky T, et al. Neural progenitors from human embryonic stem cells. Nat Biotechnol 2001;19:1134-1140.

202. Zhang SC, Wernig M, Duncan ID, Brustle O, Thomson JA. In vitro differentiation of transplantable neural precursors from human embryonic stem cells. Nat Biotechnol 2001;19:1129 1133.

203. Li XJ, Hu BY, Jones SA, et al. Directed differentiation of ventral spinal progenitors and motor neurons from human embryonic stem cells by small molecules. Stem Cells 2008;26:886-893.

204. Martinat C, Bacci JJ, Leete T, et al. Cooperative transcription activation by Nurr1 and Pitx3 induces embryonic stem cell 
maturation to the midbrain dopamine neuron phenotype. Proc Natl Acad Sci U S A 2006;103:2874-2879.

205. Pomp O, Brokhman I, Ben-Dor I, Reubinoff B, Goldstein RS. Generation of peripheral sensory and sympathetic neurons and neural crest cells from human embryonic stem cells. Stem Cells 2005;23:923-930

206. Lee G, Kim H, Elkabetz Y, et al. Isolation and directed differentiation of neural crest stem cells derived from human embryonic stem cells. Nat Biotechnol 2007;25:1468-1475.

207. Izrael M, Zhang P, Kaufman R, et al. Human oligodendrocytes derived from embryonic stem cells: Effect of noggin on phenotypic differentiation in vitro and on myelination in vivo. Mol Cell Neurosci 2007;34:310-323.

208. Hu BY, Du ZW, Li XJ, Ayala M, Zhang SC. Human oligodendrocytes from embryonic stem cells: conserved $\mathrm{SHH}$ signaling networks and divergent FGF effects. Development 2009;136:1443-1452.

209. Nistor GI, Totoiu MO, Haque N, Carpenter MK, Keirstead HS. Human embryonic stem cells differentiate into oligodendrocytes in high purity and myelinate after spinal cord transplantation. Glia 2005;49:385-396.

210. Hentze H, Graichen R, Colman A. Cell therapy and the safety of embryonic stem cell-derived grafts. Trends Biotechnol 2007;25:24-32.

211. Bjorklund LM, Sanchez-Pernaute R, Chung S, et al. Embryonic stem cells develop into functional dopaminergic neurons after transplantation in a Parkinson rat model. Proc Natl Acad Sci U S A 2002;99:2344-2349.

212. Jackson EL, Garcia-Verdugo JM, Gil-Perotin S, et al. PDGFR alpha-positive B cells are neural stem cells in the adult SVZ that form glioma-like growths in response to increased PDGF signaling. Neuron 2006;51:187-199.

213. Takahashi K, Yamanaka S. Induction of pluripotent stem cells from mouse embryonic and adult fibroblast cultures by defined factors. Cell 2006;126:663-676.

214. Yu J, Vodyanik MA, Smuga-Otto K, et al. Induced pluripotent stem cell lines derived from human somatic cells. Science 2007;318:1917-1920.

215. Nakagawa M, Koyanagi M, Tanabe K, et al. Generation of induced pluripotent stem cells without Myc from mouse and human fibroblasts. Nat Biotechnol 2008;26:101-106.

216. Wernig M, Zhao JP, Pruszak J, et al. Neurons derived from reprogrammed fibroblasts functionally integrate into the fetal brain and improve symptoms of rats with Parkinson's disease. Proc Natl Acad Sci U S A 2008;105:5856-5861.

217. Karumbayaram S, Novitch BG, Patterson M, et al. Directed differentiation of human-induced pluripotent stem cells generates active motor neurons. Stem Cells 2009;27:806-811.

218. Swistowski A, Peng J, Liu Q, et al. Efficient generation of functional dopaminergic neurons from human induced pluripotent stem cells under defined conditions. Stem Cells 2010;28:1893-1904.

219. Tsuji O, Miura K, Okada Y, et al. Therapeutic potential of appropriately evaluated safe-induced pluripotent stem cells for spinal cord injury. Proc Natl Acad Sci U S A 2010;107:1270412709.

220. Czepiel M, Balasubramaniyan V, Schaafsma W, et al. Differentiation of induced pluripotent stem cells into functional oligodendrocytes. Glia 2011;59:882-892.

221. Blakemore WF. Remyelination of CNS axons by Schwann cells transplanted from the sciatic nerve. Nature 1977;266:68-69.

222. Blakemore WF, Crang AJ. The use of cultured autologous Schwann cells to remyelinate areas of persistent demyelination in the central nervous system. J Neurol Sci 1985;70:207-223.

223. Baron-Van Evercooren A, Gansmuller A, Duhamel E, Pascal F, Gumpel M. Repair of a myelin lesion by Schwann cells transplanted in the adult mouse spinal cord. J Neuroimmunol 1992;40:235-242.

224. Baron-Van Evercooren A, Avellana-Adalid V, Lachapelle F, Liblau R. Schwann cell transplantation and myelin repair of the CNS. Mult Scler 1997;3:157-161.

225. Honmou O, Felts PA, Waxman SG, Kocsis JD. Restoration of normal conduction properties in demyelinated spinal cord axons in the adult rat by transplantation of exogenous Schwann cells. J Neurosci 1996;16:3199-3208.

226. Avellana-Adalid V, Bachelin C, Lachapelle F, Escriou C, Ratzkin $\mathrm{B}$, Baron-Van Evercooren A. In vitro and in vivo behaviour of NDF-expanded monkey Schwann cells. Eur J Neurosci 1998; 10:291-300

227. Imaizumi T, Lankford KL, Kocsis JD. Transplantation of olfactory ensheathing cells or Schwann cells restores rapid and secure conduction across the transected spinal cord. Brain Res 2000;854:70-78.

228. Kohama I, Lankford KL, Preiningerova J, White FA, Vollmer TL, Kocsis JD. Transplantation of cryopreserved adult human Schwann cells enhances axonal conduction in demyelinated spinal cord. J Neurosci 2001;21:944-950.

229. Aquino JB, Hjerling-Leffler J, Koltzenburg M, Edlund T, Villar MJ, Ernfors P. In vitro and in vivo differentiation of boundary cap neural crest stem cells into mature Schwann cells. Exp Neurol 2006;198:438-449.

230. Zujovic V, Thibaud J, Bachelin C, et al. Boundary cap cells are highly competitive for CNS remyelination: fast migration and efficient differentiation in PNS and CNS myelin-forming cells. Stem Cells 2010;28:470-479.

231. Zujovic V, Thibaud J, Bachelin C, et al. Boundary cap cells are peripheral nervous system stem cells that can be redirected into central nervous system lineages. Proc Natl Acad Sci U S A 2011;108:10714-10719.

232. Barnett SC, Hutchins AM, Noble M. Purification of olfactory nerve ensheathing cells from the olfactory bulb. Dev Biol 1993; $155: 337-350$

233. Barnett SC, Alexander CL, Iwashita Y, et al. Identification of a human olfactory ensheathing cell that can effect transplantmediated remyelination of demyelinated CNS axons. Brain 2000;123 (Pt 8):1581-1588.

234. Barnett SC, Chang L. Olfactory ensheathing cells and CNS repair: going solo or in need of a friend? Trends Neurosci 2004;27:54-60.

235. Franklin RJ, Gilson JM, Franceschini IA, Barnett SC. Schwann cell-like myelination following transplantation of an olfactory bulb-ensheathing cell line into areas of demyelination in the adult CNS. Glia 1996;17:217-224.

236. Imaizumi T, Lankford KL, Waxman SG, Greer CA, Kocsis JD. Transplanted olfactory ensheathing cells remyelinate and enhance axonal conduction in the demyelinated dorsal columns of the rat spinal cord. J Neurosci 1998;18:6176-6185.

237. Kato T, Honmou O, Uede T, Hashi K, Kocsis JD. Transplantation of human olfactory ensheathing cells elicits remyelination of demyelinated rat spinal cord. Glia 2000;30:209-218.

238. Smith PM, Lakatos A, Barnett SC, Jeffery ND, Franklin RJ. Cryopreserved cells isolated from the adult canine olfactory bulb are capable of extensive remyelination following transplantation into the adult rat CNS. Exp Neurol 2002;176:402-406.

239. Keyvan-Fouladi N, Li Y, Raisman G. How do transplanted olfactory ensheathing cells restore function? Brain Res Brain Res Rev 2002;40:325-327.

240. Santos-Benito FF, Ramon-Cueto A. Olfactory ensheathing glia transplantation: a therapy to promote repair in the mammalian central nervous system. Anat Rec B New Anat 2003;271:77-85.

241. Ramon-Cueto A, Cordero MI, Santos-Benito FF, Avila J. Functional recovery of paraplegic rats and motor axon 
regeneration in their spinal cords by olfactory ensheathing glia. Neuron 2000;25:425-435.

242. Woodhall E, West AK, Chuah MI. Cultured olfactory ensheathing cells express nerve growth factor, brain-derived neurotrophic factor, glia cell line-derived neurotrophic factor and their receptors. Brain Res Mol Brain Res 2001;88:203-213.

243. Lipson AC, Widenfalk J, Lindqvist E, Ebendal T, Olson L. Neurotrophic properties of olfactory ensheathing glia. Exp Neurol 2003;180:167-171.

244. Bjornson CR, Rietze RL, Reynolds BA, Magli MC, Vescovi AL. Turning brain into blood: a hematopoietic fate adopted by adult neural stem cells in vivo. Science 1999;283:534-537.

245. Wagers AJ, Weissman IL. Plasticity of adult stem cells. Cell 2004;116:639-648.

246. Mezey E, Chandross KJ, Harta G, Maki RA, McKercher SR. Turning blood into brain: cells bearing neuronal antigens generated in vivo from bone marrow. Science 2000;290:17791782 .

247. Mezey E, Key S, Vogelsang G, Szalayova I, Lange GD, Crain B. Transplanted bone marrow generates new neurons in human brains. Proc Natl Acad Sci U S A 2003;100:1364-1369.

248. Weimann JM, Johansson CB, Trejo A, Blau HM. Stable reprogrammed heterokaryons form spontaneously in Purkinje neurons after bone marrow transplant. Nat Cell Biol 2003;5:959-966.

249. Wislet-Gendebien S, Hans G, Leprince P, Rigo JM, Moonen G, Rogister B. Plasticity of cultured mesenchymal stem cells: switch from nestin-positive to excitable neuron-like phenotype. Stem Cells 2005;23:392-402.

250. Cogle CR, Yachnis AT, Laywell ED, et al. Bone marrow transdifferentiation in brain after transplantation: a retrospective study. Lancet 2004;363:1432-1437.

251. Kopen GC, Prockop DJ, Phinney DG. Marrow stromal cells migrate throughout forebrain and cerebellum, and they differentiate into astrocytes after injection into neonatal mouse brains. Proc Natl Acad Sci U S A 1999;96:10711-10716.

252. Akiyama Y, Radtke C, Kocsis JD. Remyelination of the rat spinal cord by transplantation of identified bone marrow stromal cells. J Neurosci 2002;22:6623-6630.

253. Inoue M, Honmou O, Oka S, Houkin K, Hashi K, Kocsis JD. Comparative analysis of remyelinating potential of focal and intravenous administration of autologous bone marrow cells into the rat demyelinated spinal cord. Glia 2003;44:111-118.

254. Alvarez-Dolado M, Pardal R, Garcia-Verdugo JM, et al. Fusion of bone-marrow-derived cells with Purkinje neurons, cardiomyocytes and hepatocytes. Nature 2003;425:968-973.

255. Mitome M, Low HP, van den Pol A, et al. Towards the reconstruction of central nervous system white matter using neural precursor cells. Brain 2001;124:2147-2161.

256. Blakemore WF, Franklin RJ. Transplantation options for therapeutic central nervous system remyelination. Cell Transplant 2000;9:289-294.

257. Tourbah A, Linnington C, Bachelin C, Avellana-Adalid V, Wekerle H, Baron-Van Evercooren A. Inflammation promotes survival and migration of the CG4 oligodendrocyte progenitors transplanted in the spinal cord of both inflammatory and demyelinated EAE rats. J Neurosci Res 1997;50:853861 .

258. Armstrong RC, Harvath L, Dubois-Dalcq ME. Type 1 astrocytes and oligodendrocyte-type 2 astrocyte glial progenitors migrate toward distinct molecules. J Neurosci Res 1990;27:400-407.

259. Zhang H, Vutskits L, Calaora V, Durbec P, Kiss JZ. A role for the polysialic acid-neural cell adhesion molecule in PDGF-induced chemotaxis of oligodendrocyte precursor cells. J Cell Sci 2004;117:93-103.
260. Osterhout DJ, Ebner S, Xu J, Ornitz DM, Zazanis GA, McKinnon RD. Transplanted oligodendrocyte progenitor cells expressing a dominant- negative FGF receptor transgene fail to migrate in vivo. J Neurosci 1997;17:9122-9132.

261. Spassky N, de Castro F, Le Bras B, et al. Directional guidance of oligodendroglial migration by class 3 semaphorins and netrin-1. J Neurosci 2002;22:5992-6004.

262. Cohen RI, Rottkamp DM, Maric D, Barker JL, Hudson LD. A role for semaphorins and neuropilins in oligodendrocyte guidance. J Neurochem 2003;85:1262-1278.

263. Merchan P, Bribian A, Sanchez-Camacho C, Lezameta M, Bovolenta P, de Castro F. Sonic hedgehog promotes the migration and proliferation of optic nerve oligodendrocyte precursors. Mol Cell Neurosci 2007;36:355-368.

264. Erlandsson A, Larsson J, Forsberg-Nilsson K. Stem cell factor is a chemoattractant and a survival factor for CNS stem cells. Exp Cell Res 2004;301:201-210.

265. Bagri A, Gurney T, He X, et al. The chemokine SDF1 regulates migration of dentate granule cells. Development 2002;129:4249 4260.

266. Dziembowska M, Tham TN, Lau P, Vitry S, Lazarini F, DuboisDalcq M. A role for CXCR4 signaling in survival and migration of neural and oligodendrocyte precursors. Glia 2005;50:258 269.

267. Reiss K, Mentlein R, Sievers J, Hartmann D. Stromal cellderived factor 1 is secreted by meningeal cells and acts as chemotactic factor on neuronal stem cells of the cerebellar external granular layer. Neuroscience 2002;115:295-305.

268. Belmadani A, Tran PB, Ren D, Assimacopoulos S, Grove EA, Miller RJ. The chemokine stromal cell-derived factor-1 regulates the migration of sensory neuron progenitors. J Neurosci 2005;25:3995-4003.

269. Stumm RK, Zhou C, Ara T, et al. CXCR4 regulates interneuron migration in the developing neocortex. J Neurosci 2003;23:5123-5130.

270. Fricker-Gates RA, Winkler C, Kirik D, Rosenblad C, Carpenter MK, Bjorklund A. EGF infusion stimulates the proliferation and migration of embryonic progenitor cells transplanted in the adult rat striatum. Exp Neurol 2000;165:237-247.

271. Zhang H, Vutskits L, Pepper MS, Kiss JZ. VEGF is a chemoattractant for FGF-2-stimulated neural progenitors. J Cell Biol 2003; 163:1375-1384.

272. Godiska R, Chantry D, Dietsch GN, Gray PW. Chemokine expression in murine experimental allergic encephalomyelitis. J Neuroimmunol 1995;58:167-176.

273. Pluchino S, Quattrini A, Brambilla E, et al. Injection of adult neurospheres induces recovery in a chronic model of multiple sclerosis. Nature 2003;422:688-694.

274. Mahmood A, Lu D, Chopp M. Intravenous administration of marrow stromal cells (MSCs) increases the expression of growth factors in rat brain after traumatic brain injury. J Neurotrauma 2004; 21:33-39.

275. Tran PB, Ren D, Veldhouse TJ, Miller RJ. Chemokine receptors are expressed widely by embryonic and adult neural progenitor cells. J Neurosci Res 2004;76:20-34.

276. Prestoz L, Relvas JB, Hopkins K, et al. Association between integrin-dependent migration capacity of neural stem cells in vitro and anatomical repair following transplantation. Mol Cell Neurosci 2001;18:473-484.

277. Brocke S, Piercy C, Steinman L, Weissman IL, Veromaa T. Antibodies to CD44 and integrin alpha4, but not L-selectin, prevent central nervous system inflammation and experimental encephalomyelitis by blocking secondary leukocyte recruitment. Proc Natl Acad Sci U S A 1999;96:6896-6901.

278. Rampon C, Weiss N, Deboux C, et al. Molecular mechanism of systemic delivery of neural precursor cells to the brain: assembly 
of brain endothelial apical cups and control of transmigration by CD44. Stem Cells 2008;26:1673-1682.

279. Ruster B, Gottig S, Ludwig RJ, et al. Mesenchymal stem cells display coordinated rolling and adhesion behavior on endothelial cells. Blood 2006;108:3938-3944.

280. Shyu WC, Chen CP, Lin SZ, Lee YJ, Li H. Efficient tracking of non-iron-labeled mesenchymal stem cells with serial MRI in chronic stroke rats. Stroke 2007;38:367-374.

281. Sadan O, Shemesh N, Barzilay R, et al. Migration of neurotrophic factors-secreting mesenchymal stem cells toward a quinolinic acid lesion as viewed by magnetic resonance imaging. Stem Cells 2008;26:2542-2551.

282. Brustle O, Choudhary K, Karram K, et al. Chimeric brains generated by intraventricular transplantation of fetal human brain cells into embryonic rats. Nat Biotechnol 1998;16:1040-1044.

283. Flax JD, Aurora S, Yang C, et al. Engraftable human neural stem cells respond to developmental cues, replace neurons, and express foreign genes. Nat Biotechnol 1998;16:10331039.

284. O'Leary MT, Blakemore WF. Oligodendrocyte precursors survive poorly and do not migrate following transplantation into the normal adult central nervous system. J Neurosci Res 1997;48:159-167.

285. Einstein O, Ben-Menachem-Tzidon O, Mizrachi-Kol R, Reinhartz E, Grigoriadis N, Ben-Hur T. Survival of neural precursor cells in growth factor-poor environment: Implications for transplantation in chronic disease. Glia 2006;53:449-455.

286. Caimi PF, Reese J, Lee Z, Lazarus HM. Emerging therapeutic approaches for multipotent mesenchymal stromal cells. Curr Opin Hematol 2010;17:505-513.

287. Karussis D, Karageorgiou C, Vaknin-Dembinsky A, et al. Safety and immunological effects of mesenchymal stem cell transplantation in patients with multiple sclerosis and amyotrophic lateral sclerosis. Arch Neurol 2010;67:1187-1194. 